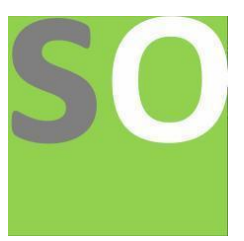

Article title: A Technical and Industrial Analysis of Global Plastics Market, Trade, Financing, and Operations Authors: Fatih Selim Yildizhan[1]

Affiliations: LL.M., University of Fribourg, Fribourg Switzerland[1]

Orcid ids: 0000-0002-5552-4763[1]

Contact e-mail: fsyildizhan@gmail.com

License information: This work has been published open access under Creative Commons Attribution License $\mathrm{http}: / / c r e a t i v e c o m m o n s . o r g / l i c e n s e s / b y / 4.0 /$, which permits unrestricted use, distribution, and reproduction in any medium, provided the original work is properly cited. Conditions, terms of use and publishing policy can be found at https://www.scienceopen.com/.

Preprint statement: This article is a preprint and has not been peer-reviewed, under consideration and submitted to ScienceOpen Preprints for open peer review.

DOI: 10.14293/S2199-1006.1.SOR-.PPDUNRN.v1

Preprint first posted online: 30 January 2021

Keywords: plastics market, plastic recycling, global plastic market, polymer market, low-density polyethylene , high-density polyethylene, Polypropylene 


\title{
A TECHNICAL AND INDUSTRIAL ANALYSIS OF GLOBAL PLASTICS MARKET, TRADE, FINANCING, AND OPERATIONS
}

\author{
January 2021 \\ Fatih Selim Yildizhan \\ LL.M. University of Fribourg, Switzerland \\ Commodity Trading \\ $\&$ \\ International Business Law
}




\section{TABLE OF CONTENTS}

\section{ABSTRACT}

LIST OF ABBREVIATIONS

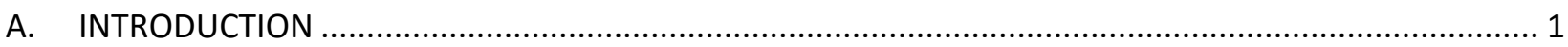

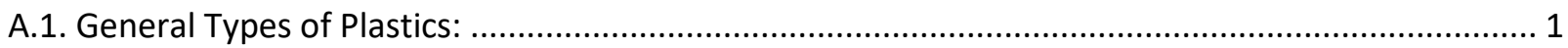

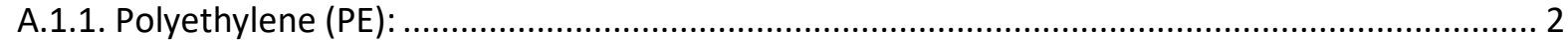

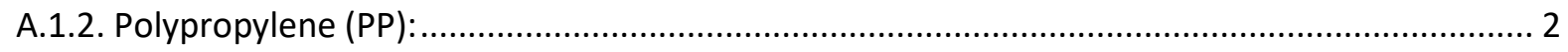

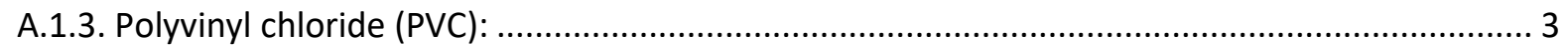

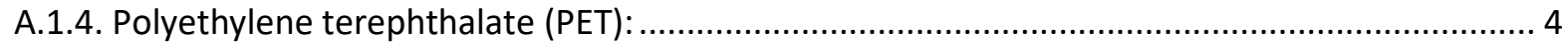

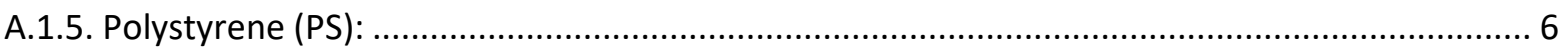

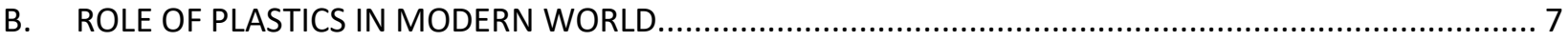

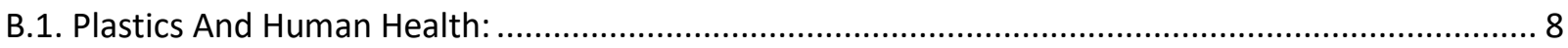

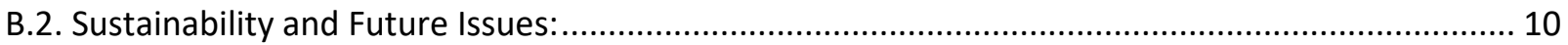

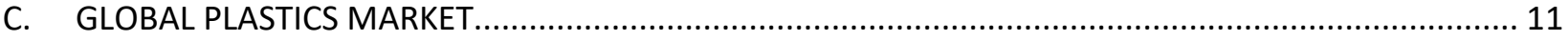

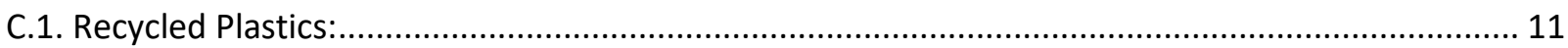

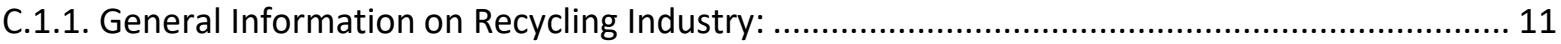

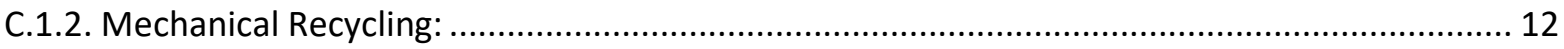

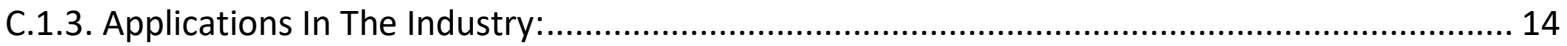

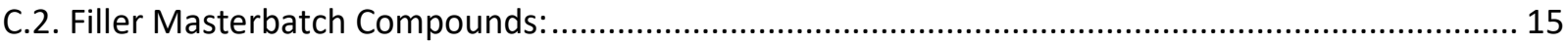

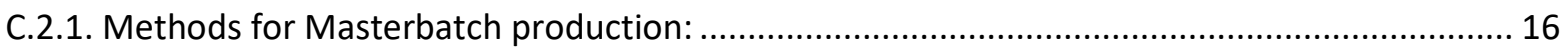

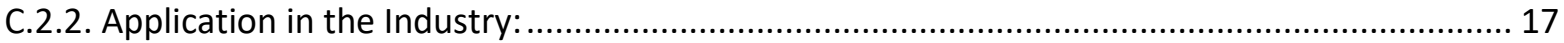

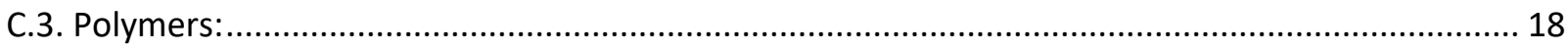

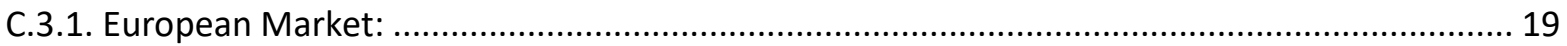

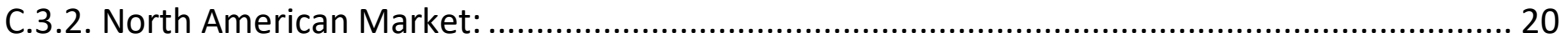

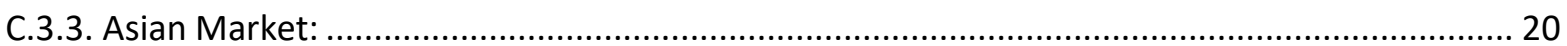

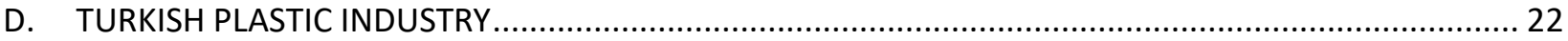

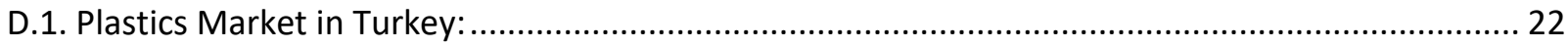

D.2. Masterbatches - Comparison Between Turkey and Global Market:........................................ 22 
D.3. Recycling in Turkey - Comparison To Global Market: ............................................................ 23

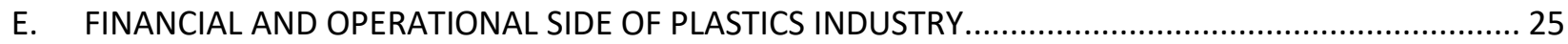

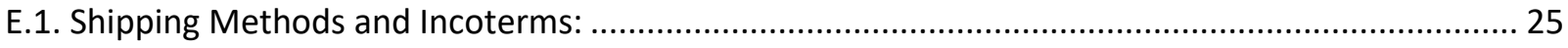

E.2. Payment Methods In Global Plastic Trade: ........................................................................ 27

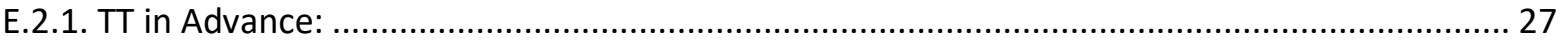

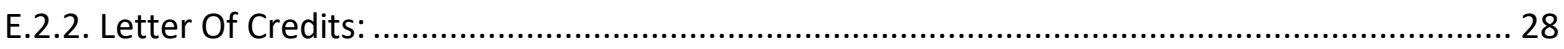

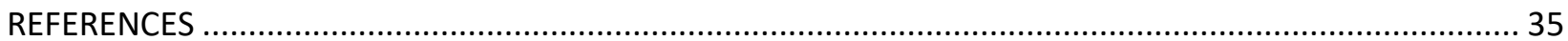


ABSTRACT

Plastics are synthetic or semi-synthetic meltable substances that can be modeled in solid objects. In the modern world, it seems impossible today to live without plastic or synthetic polymers, which production and usage only go back to 1950 . While plastics play a central role in modern society, the production of safer and cleaner products for potential use is required for decreasing the negative environmental effects.

The purpose of this article is to analyze the plastic industry, the role of plastics in our social life, the situation in the plastics market, plastic recycling, and masterbatch compound production.

For the purpose of this article, the main markets which have been analyzed are; Europe, Asia, and North America. There is a specific part focusing on Turkey who ranks 6th in terms of plastics processing capacity in Europe and has a huge plastic waste mismanagement problem.

Finally, there is an analysis of the financial and operational side of global plastics trading, contract terms, and payment methods, which are being used today by the companies who are operating in the petrochemical industry and commodity trade financing generally. 


\section{LIST OF ABBREVIATIONS}

\begin{tabular}{|c|c|}
\hline APP & Atactic Polypropylene \\
\hline ASTM & American Society for Testing and Materials \\
\hline BPA & Bisphenol A \\
\hline $\mathrm{CaCO} 3$ & Calcium Carbonate \\
\hline $\mathrm{CD}$ & Compact Disc \\
\hline CFR & Cost and Freight \\
\hline CIF & Cost, Insurance \& Freight \\
\hline CIP & Carriage and Insurance Paid To \\
\hline CNT & Carbon Nanotube \\
\hline COVID-19 & Coronavirus Disease 2019 \\
\hline $\mathrm{CPE}$ & Chlorinated Polyethylene \\
\hline CPT & Carriage Paid To \\
\hline DAP & Delivery at Place \\
\hline DDP & Delivery Duty Paid \\
\hline DEHP & Di(2-Ethylhexyl) Phthalate \\
\hline DPU & Delivered at Place Unloaded \\
\hline ECHA & The European Chemicals Agency \\
\hline ECTC & Engineering Chemical Technological Center \\
\hline EDC & Ethylene Dichloride \\
\hline EPR & Ethylene Propylene Rubber \\
\hline E-PVC & Emulsion Polyvinyl Chloride \\
\hline ESC & Environmental Stress Cracking \\
\hline ESCR & Environmental Stress Cracking Resistance \\
\hline
\end{tabular}




\begin{tabular}{|c|c|}
\hline $\mathrm{ESD}-\mathrm{C}$ & Electro-Static Dissipative Compounds \\
\hline EU & European Union \\
\hline EXW & Ex Works \\
\hline FAS & Free Alongside Ship \\
\hline FCA & Free Carrier \\
\hline FOB & Free on Board \\
\hline GCC & Ground Calcium Carbonate \\
\hline HDPE & High-Density Polyethylene \\
\hline HMWPE & High-Molecular-Weight Polyethylene \\
\hline ICC & International Chamber of Commerce \\
\hline iPP & Isotactic Polypropylene \\
\hline $\mathrm{Kg}$ & Kilogram \\
\hline $\mathrm{LC}$ & Letter of Credit \\
\hline LDPE & Low-Density Polyethylene \\
\hline LLDPE & Linear Low-Density Polyethylene \\
\hline MDPE & Medium-Density Polyethylene \\
\hline Mt & Metric Tons \\
\hline NIR & Near-Infrared \\
\hline PAGEV & $\begin{array}{l}\text { Foundation of Turkish Plastics Industrialists Research, Development, } \\
\text { and Education }\end{array}$ \\
\hline PB-1 & Polybutene-1 \\
\hline PCC & Precipitated Calcium Carbonate \\
\hline PE & Polyethylene \\
\hline PET & Polyethylene Terephthalate \\
\hline PEX & Crosslinked Polyethylene \\
\hline PIB & Polyisobutylene \\
\hline
\end{tabular}




\begin{tabular}{|c|c|}
\hline PMP & Polymethyl Pentene \\
\hline POE & Polyolefin Elastomers \\
\hline PP & Polypropylene \\
\hline PPC & Polypropylene Copolymer \\
\hline $\mathrm{PPH}$ & Polypropylene Homopolymer \\
\hline PPRC & Polypropylene Random Copolymer \\
\hline PS & Polystyrene \\
\hline PVC & Polyvinyl Chloride \\
\hline $\mathrm{REACH}$ & Registration, Evaluation, Authorization, And Restriction of Chemicals \\
\hline sPP & Syndiotactic Polypropylene \\
\hline S-PVC & Suspension Polyvinyl chloride \\
\hline SWIFT & Society for Worldwide Interbank Financial Telecommunication \\
\hline TT & Telegraphic Transfer \\
\hline US. & the United States \\
\hline USA. & The United States of America \\
\hline UHMWPE & Ultra-High-Molecular-Weight Polyethylene \\
\hline UK & The United Kingdom \\
\hline ULMWPE & Ultra-Low-Molecular-Weight Polyethylene \\
\hline UV & Ultraviolet \\
\hline $\mathrm{VCM}$ & Vinyl Chloride Monomer \\
\hline VLDPE & Very-Low-Density Polyethylene \\
\hline Wt. & Weight Percent \\
\hline
\end{tabular}





\section{A. INTRODUCTION}

Plastics are a number of synthetic or semi-synthetic meltable substances that can be modeled in solid objects ${ }^{1}$.

Plasticity is the general property of all the materials that can bend irreversibly without breakage. However, for moldable polymers, this happens to such an extent, and therefore the term comes from this particular capacity. Plastics are high molecular mass organic polymers and often contain other materials. They are most typically synthetic, petrochemicals based. There is also an array of variants made from renewable materials. ${ }^{2}$

\section{A.1. General Types of Plastics:}

There are different types of plastics for use in different types of productions in different sectors. The most commonly used plastics today are; Polyethylene (PE), Polypropylene (PP), Polyvinyl chloride (PVC), Polyethylene terephthalate (PET), Polystyrene (PS). According to the market data of 2015, the market shares of these plastics are as below; ${ }^{3}$

Global Commodity Plastic Market Share (\%), By Type (2015)

(Market Research Future, 2017)

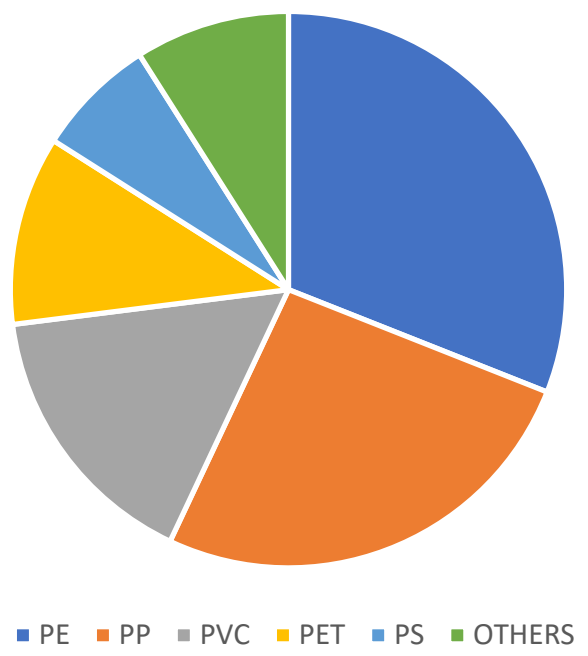

${ }^{1}$ (Dassault Systèmes, 2020)

2 (Loca, 2020)

${ }^{3}$ (Market Research Future, 2017) 


\section{A.1.1. Polyethylene (PE):}

Polyethylene is one of the world's most-produced plastics; it is a lightweight and durable thermoplastic with a variable crystalline structure. Polyethylene is used in the film, tube, plastic, laminate, and other applications in many industries such as packaging, automotive, electrical, etc.

Polyethylene is made of ethylene (olefin) monomers by addition or radical polymerization. The polymerization of polyethylene is carried out using the Ziegler-Natta and Metallocene catalysts.

PE forms part of the polyolefin family of polymers and is classed by density. The most common types of polyethylene are Low-density polyethylene (LDPE) and High-density polyethylene (HDPE).

Low-density polyethylene (LDPE) and Linear low-density polyethylene (LLDPE) are branched versions of the PE, and High-density polyethylene (HDPE), Ultra-high-molecular-weight polyethylene (UHMWPE) are linear versions of the PE.

There are also crosslinked polyethylenes (PEX or XLPE) with crosslink structures specifically designed for various applications.

$\mathrm{PE}$ is also available in other forms, for example, medium-density polyethylene (MDPE), very-lowdensity polyethylene (VLDPE), high-molecular-weight polyethylene (HMWPE), ultra-low-molecularweight polyethylene (ULMWPE), chlorinated polyethylene (CPE).

Some of the most known polyethylene suppliers are Borealis, Celanese Corporation, Dow Chemicals, ExxonMobil Chemical, LyondellBasell, NOVA Chemicals, SABIC. See all Polyethylene Suppliers ${ }^{4}$.

\section{A.1.2. Polypropylene (PP):}

PP also belongs to the polyolefin family of polymers and is one of the top three widely used polymers today. Polypropylene is used in plastic and fiber, mainly for automotive, consumer goods, furniture market, and other industrial applications such as construction.

During polymerization, PP can form three basic sequences depending on the base of the methyl groups; atactic (aPP) irregular methyl group (CH3) arrangement, isotactic (iPP) methyl groups (CH3) arranged on one side of the carbon chain, syndiotactic (sPP)alternating methyl group (CH3) arrangement.

Among the commodity plastics, PP has the lowest density. Some of the most renowned polyethylene suppliers are; Schulman (GAPEX ${ }^{\circledR}$, ACCUTECH $^{\mathrm{TM}}$, POLYFORT $^{\circledR}$, Fiberfil $^{\circledR}$, FERREX $^{\circledR}$ ), Borealis (Daplen ${ }^{\mathrm{TM}}$, Bormed $^{\mathrm{TM}}$, Fibremod ${ }^{\mathrm{TM}}$ ), ExxonMobil Chemical (ExxonMobil ${ }^{\mathrm{TM}}$, Achieve $^{\mathrm{TM}}$ ), LyondellBasell (Adstif, Circulen, Hifax, Hostacom, Moplen), SABIC (SABIC ${ }^{\circledR}$ PP, SABIC ${ }^{\circledR}$ Vestolen, LNP ${ }^{\text {TM }}$ THERMOCOMP ${ }^{\mathrm{TM}}$ ), RTP Company (ESD C, ESD A, RTP 100, RTP 101 to 109).

\footnotetext{
${ }^{4}$ (Special Chem, 2020)
} 


\section{PP Colopolymer / PP Homopolymer:}

The most commonly used form is a polypropylene homopolymer. It only comprises a propylene monomer in the form of semi-crystalline. Packaging, textiles, medicals, piping, automotive, and electrical applications are the primary applications.

The polypropylene copolymer family shall be divided into random copolymers and copolymer blocks formed by propane and ethane polymerization:

1. The random copolymer is formed by polymerizing ethene and propene together. The Ethene units are randomly inserted into the polypropylene chains, typically by up to $6 \%$ in mass. These polymers are elastic and optically transparent, allowing for translucent applications, and need a transparent appearance.

2. Polypropylene Block Copolymer has a larger ethene content, usually from 5 to $15 \%$. It is arranged in regular blocks of co-monomers. It is, therefore, durable and less flexible than the random copolymer. These polymers are suitable for high strength applications, such as industrial settings.

The physical or mechanical properties of PP can be further enhanced by polymer additives such as clarifiers, flame retardants, glass fibers, minerals, conductive fillers, lubricants, colorants, and many other additives. If PP has low UV resistance, additives as obstructed amines provide quick stability and boost service life compared with non - modified polypropylene. Further, fillers and additives are added, achieving better properties for manufacturing and end-use applications.

The production and use of new additives, modern processes for polymerization, and mixing solutions improved polypropylene efficiency. Therefore, today PP is less regarded as a low cost but rather as a high-performance material that rivals conventional plastic engineering and sometimes even metal ${ }^{5}$.

\section{A.1.3. Polyvinyl chloride (PVC):}

Polyvinyl chloride is a thermoplastic polymer that is cost-effective and flexible and commonly used in applications such as building and construction systems, manufacturing of doors or windows, pipes, wire and cable insulating systems, medical systems. It is in volume after polyethylene and polypropylene, the third-largest thermoplastic material being used today. ${ }^{6}$

The substance is white, soft, and stable in the form of powder or granulates. PVC has replaced conventional building materials (such as wood, metal, concrete, rubber, ceramics, etc.) due to its versatile features, such as lightweight, durable, inexpensive, and easy to process.

\footnotetext{
${ }^{5}$ (SpecialChem, 2020)

${ }^{6}$ (SpecialChem , 2020)
} 
Some of the most known suppliers are; Sylvin Technologies, Teknor Apex, Colorite Compounds (Tekni-Plex), Inovyn, Ineos, and SABIC.

\section{How PVC manufactured?}

Vinyl chloride monomer (VCM) is produced from the chlorination of ethylene and pyrolysis of the resulting ethylene dichloride (EDC) in a cracking unit. PVC is produced by polymerization of vinyl chloride monomer (VCM).

The most common methods for the commercial production of PVC are; Suspension PVC (S-PVC) and Emulsion PVC (E-PVC).

\section{Suspension PVC (S-PVC) Process:}

The monomer is added with an initiator of polymerization and other additives in the pressureresistant reactor. In order to maintain a suspension and ensure uniform particle size for PVC resin, the material of the reaction vessel is continuously being mixed.

Usually, polymerized PVC suspension has an average particle size of 100-150 $\mu \mathrm{m}$ for the $50-250 \mu \mathrm{m}$ range. S-PVC grades are designed to satisfy a wide range of requirements, such as high plasticizing absorption, high bulk density, and good powder flow for rigid extrusion products.

\section{Bulk or Emulsion (E-PVC) Process:}

With E-PVC, the primary particles are solid and fluid-surfaced spheres grouped into irregularly formed aggregates with a standard average particle size of between 40 and $50 \mu \mathrm{m}$, varying from 0,1 to $100 \mu \mathrm{m}$. E-PVC resin applications include dipping, coating, and spreading.

Differences between S-PVC and E- PVC can be listed as below;

- S-PVC has a lower flexible PVC formula cost, and E-PVC has higher flexible PVC formula costs.

- The S-PVC particles are mixed with plasticizers and can be extruded into pellets, which are also used for extrusion, calendaring, and injection molding processing. The E-PVC powder can be combined with plasticizers to create a paste that is also used to coat, dip, and spray.

- S-PVC processing equipment is usually more expensive than E-PVC processing equipment.

\section{A.1.4. Polyethylene terephthalate (PET):}

Polyethylene terephthalate (PET or PETE) is a thermoplastic polymer of common use and part of the polymer composite family. PET resins have an excellent combination of mechanical, thermal, chemical, and dimensionally stable properties. 
PET is one of the most recycled thermoplastic materials with a recycling number of "1". Recycled PET can be used in fibers, fabrics, packing sheets, and car parts processing. Chemically, terephthalate polyethylene is very similar to Polybutylene Terephthalate.

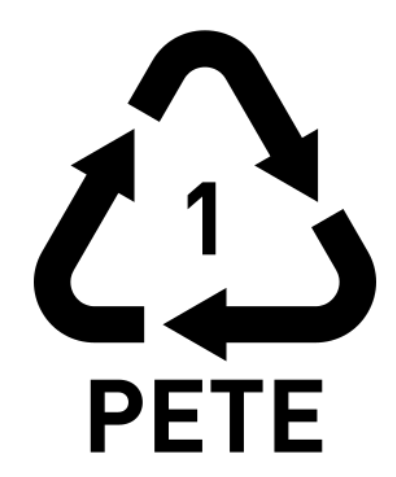

Resin code for PET according to The ASTM International Resin Identification Coding System

In its natural form, PET is extremely adaptable, colorless, and half-crystalline resin. It can be semirigid or rigid, depending on how it is processed. It demonstrates good thermal stability and resistance to impact, humidity, alcohol, and solvents.

Commercially available PET grades usually need higher strength and higher thermal resistance. The addition of fillers like glass fibers, CNT's, etc., leads to the enhancement of impact resistance, which can be used in surface finish and wrapping.

The main applications of Polyethylene Terephthalate are usually in the packaging industry. PET is a strong moisture and water barrier product. For mineral water and carbonated soft drinks, PET plastic bottles are commonly used. Also, With their high mechanical strength, PET films are suitable for use in tape applications. Unoriented PET sheets can be used for packaging trays and blistering. It is particularly appropriate for food-packing applications due to its chemical inertness and other physical properties. Other uses for packaging include rigid cosmetic jars, microwave pots, transparent films, etc.

PET monofilament is primarily widely used in the manufacture of mesh materials for screen printing, oil and sand filter, greenhouses, woven / knitting belts, and filter cloth, among other fields.

PET has wide textile applications too. Durability and extra gain of reduced wrinkles and shrinkage over cotton are properties of polyester ${ }^{7}$. The products in polyester are lightweight, wind-shrinky, dragresistant, and tear-resistant.

PET is commonly used in the electrical and electronic industries due to its electrical insulating properties, high structural and dimensional stability. The polymer replaces cast metals and thermosets in electrical encapsulations, solenoid systems, intelligent meters, solar link boxes, photovoltaic components, etc. The excellent flow features of PET make it possible to manufacture high-performance components free of design and miniaturization.

\footnotetext{
${ }^{7}$ PET is often referred to in textile applications as "polyester", although in packaging, the acronym PET is typically used.
} 


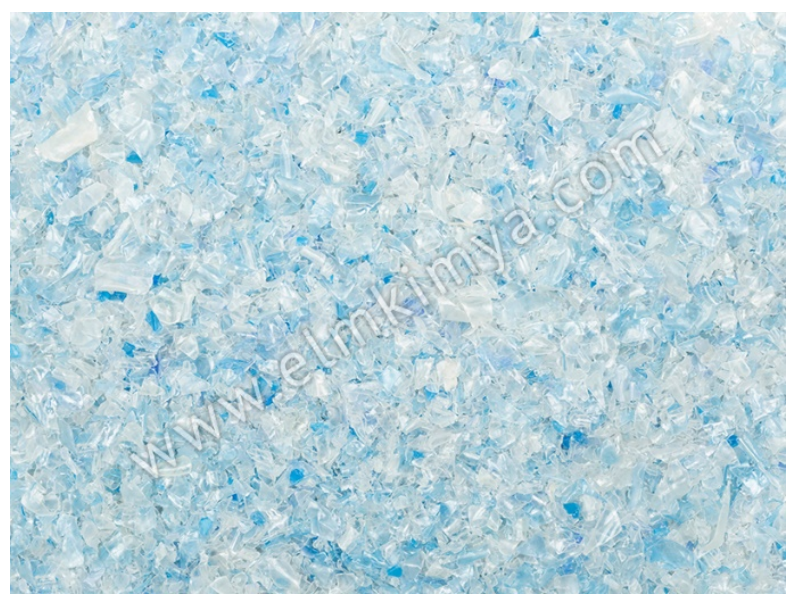

Recycled PET Flakes

Also, in the automotive industry, PET is successfully used. It is currently used for wipers and gear carriages, headlamp retainer, engine cover, plugs.

\section{A.1.5. Polystyrene (PS):}

Polystyrene (PS) is a naturally transparent thermoplastic and accessible both as a standard solid plastic and rigid foam form. PS polymers are often used for commercial packaging and are also widely used in several consumer goods applications.

Dow Chemical Company designed and trademarked the popular polystyrene foam product "styrofoam" in 1941. For packing applications, polystyrene is most commonly used as the foam shape. Styrofoam is used in many restaurants for the use of "to-go" containers and tableware.

Among the environmental groups, the material is controversial because it is slow to biodegrade and more and more present in environmental pollution, especially in the form of foam, which makes the materials floating in waterways and the ocean.

The solid plastic-type polystyrene is widely used as a container for foods like yogurt or medical applications such as test tubes or Petri dishes, or day-to-day materials such as CDs.

Like other plastics, the polystyrene manufacturing process starts with the distillation of hydrocarbons in light groups, called "fractions," some are combined with other catalysts (through the polymerization process) ${ }^{8}$.

${ }^{8}$ (Rogers, 2015) 


\section{B. ROLE OF PLASTICS IN MODERN WORLD}

The word "plastics" was invented in 1907 for the world's first fully synthetic plastic. After that, the types of plastics have their specific names according to their chemical formulas and ingredients. Lots of scientists contributed to polymer materials science. German scientist Hermann Staudinger was considered "the father of polymer chemistry."

Roughly a third of plastic is used in packaging in industrialized economies and about the same for buildings in applications such as piping, plumbing, or vinyl siding. Further applications include cars, furniture, and household items. However, plastic applications may vary in developing countries. For instance, $42 \%$ of India's plastic use is packaging consumption. About $50 \mathrm{~kg}$ of plastic is produced globally per person every year, and every ten years, the amount is doubled.

Today it seems impossible to have a world without plastic or synthetic organic polymers. Massive production and usage of plastics go back to 1950. While the first synthetic plastics, such as Bakelite, began to emerge at the beginning of the 20th century, large-scale usage of plastics outside of military activity only occurred after the Second World War. The rapid growth resulting from the manufacture of plastics is exceptional and exceeds any other materials produced by man, include products such as steel and cement, which are commonly used in the building industry. ${ }^{9}$

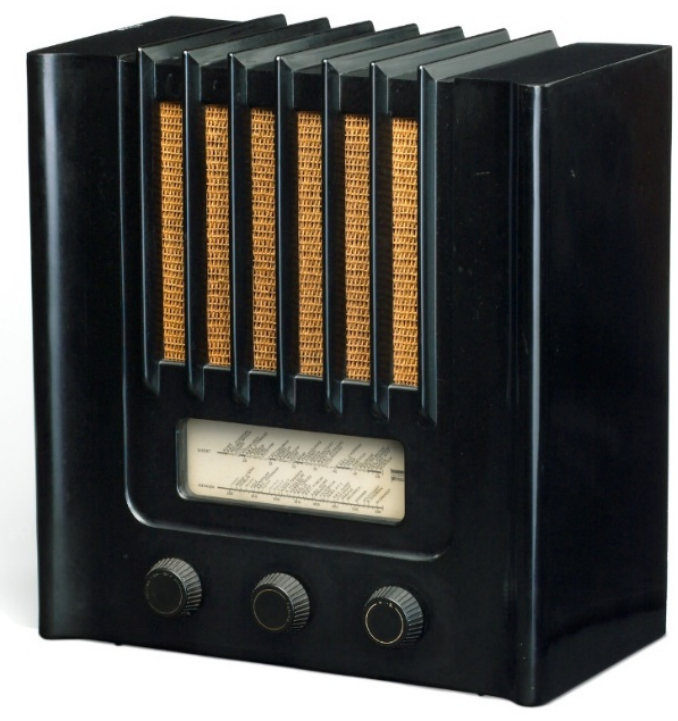

This is a Murphy radio with a brown Bakelite plastic case dated $1940^{10}$.

\footnotetext{
${ }^{9}$ (Geyer, Jambeck, \& Law, 19 Jul 2017) p1.

${ }^{10}$ (WARING, 2017)
} 
Most of the industrial materials were replaced by plastics today despite the environmental monitoring over these materials. However, the future of plastics is uncertain. To date, 8300 million tons of virgin plastics are estimated to have been produced. Around 6300 tonnes, of which about $9 \%$ were recycled, $12 \%$ were burned and $79 \%$ accumulated in sites and the natural environment, until 2015 . By 2050, approximately $12.000 \mathrm{Mt}$ of plastic waste would be in depots or the natural environment if current development and waste management patterns continue ${ }^{11}$.

Plastics' biggest market is packaging, which is proliferating by a global transition from single-use to reusable containers. In medium and high-income countries, plastics (by mass) in municipal solid waste increased from less than $1 \%$ in 1960 to over $10 \%$ in 2005. Simultaneously, over the past five years, the global production of solid waste, closely linked to gross national income per capita, has risen steadily ${ }^{12}$.

The overwhelming majority of the monomers, including ethylene and polypropylene, are used to make plastics. These compounds come from fossil hydrocarbons. No plastics are biodegradable in all of the typical applications. So, instead of dissolving, they accumulate in deposits or the natural world. Only destructive thermal treatment, including combustion or pyrolysis, will permanently remove plastic waste. Therefore, a solution is almost mandatory for contamination of the natural environment with plastic waste.

Marine waste is also an excellent problem for ocean basins, and currently, plastic wastes have piled up in the marine ecosystem; in 2010 alone, an estimated 4 million to 12 million tons of plastic waste have been reported onshore. Environmental pollution of freshwater systems is increasingly considered a big problem for the ecosystem.

\section{B.1. Plastics And Human Health:}

Plastics are necessary materials in modern life, public health, and medicine. Human society relies heavily on plastics because of its resistance to chemical, physical, and biological degradation. This applies particularly to the healthcare industry. Like many other industrial plastics applications, plastics' flexibility is a crucial advantage for medicine and public health combined with a low cost, which has allowed the mass production of usable and hygienic disposable health care goods ${ }^{13}$.

However, plastics pose various possible health and environmental threats because of the widespread use of the numerous additives found in them. ${ }^{14}$

There is a monomeric structure of polycarbonate plastics known as "Bisphenol A (BPA), which was first synthesized in 1891. It is sometimes used as an additive to other plastics like polyvinyl chloride

\footnotetext{
${ }^{11}$ (Geyer, Jambeck, \& Law, 19 Jul 2017) p.1.

12 (Geyer, Jambeck, \& Law, 19 Jul 2017) p.2.

13 (Halde, January 13, 2010) p.179.

14 (Halde, January 13, 2010) p.180.
} 
(PVC). According to an estimation in 2003, the worldwide annual output of BPA is more than 2.2 million metric tons. ${ }^{15}$

A large portion of BPA is brought into contact with food. Since BPA polymerization releases certain monomers, BPA molecules will, over time, be released from beverages and food containers. Repeated washings of containers and storage of acidic or simple materials breaking up the polymer intensify the leaching process. ${ }^{16}$

Recycled water bottles, baby bottles, and internal linings of food containers, all manufactured from BPA; these products are known to elute the unhealthy monomers into nutrition. Though food is regarded as the primary source of exposure, combustion can also contribute to additional environmental exposures. Due to the global drug development process, a synthesis alone releases an estimated 100 tons into the atmosphere per year. Additional airborne exposures can usually happen during the offgassing of the material from consumer products and vaporization from contaminated water. ${ }^{17}$

Phthalates are also a complex group of widely used compounds in industry. They are phthalic acid diesters, which is a compound called "benzene dicarboxylic acid." Phthalates manufactured in a large quantity in our society since the 1930s and are used in industrial plastic products, household goods, paints, medical devices, children's toys, cosmetics, lotion, sunscreens, and perfumes. ${ }^{18}$

The characteristics of the phthalates rely on the dialkyl or alkyl charge density and fracturing. There are more than 25 common esters of phthalate. As plasticizers, phthalates are used in plastics to provide durability and elasticity. Phthalates constitute $70 \%$ of the US market for plasticizers. In comparison with BPA monomers in polycarbonate plastics, by their nature, the phthalate is not covalently connected to the polymer matrix, making it very leaching-sensitive. The phthalates are existing surprisingly highly in plastics. ${ }^{19}$

After the phthalates have been introduced into the human body, they are quickly metabolized in hours. Phthalate dieters also undergo a biphasic metabolism by hydrolyzing or oxidation and then conjugating. Following initial metabolism, the resultant monoesters may again be subjected to transformation or immediately be excreted in urine and feces. Instead of a specific compound, biomonitoring targets monoesters and other metabolites ideally. This approach enhances the risk of false detections from background phthalate concentrations omnipresent in indoor air and plastic equipment used for testing and processing samples. ${ }^{20}$

\footnotetext{
15 (Halde, January 13, 2010) p. 181.

${ }^{16}$ (Halde, January 13, 2010) p. 181.

17 (Halde, January 13, 2010) p 181.

18 (Halde, January 13, 2010) p. 184.

${ }^{19}$ (Halde, January 13, 2010) p. 185.

${ }^{20}$ (Halde, January 13, 2010) p. 185.
} 


\section{B.2. Sustainability and Future Issues:}

Apart from the danger to human health, the increase in extremely hazardous plastics for disposable consumer goods with durability is unsustainable. Manufacturing of plastics makes $8 \%$ of global oil usage, $4 \%$ raw material, and $4 \%$ of energy consumption for production. For disposable items production, onethird of the operation requires plastics. Highly durable synthetic plastic packaging is wasteful and unsustainable. Besides, many plastics have an incredibly short life cycle measured in timescales of seconds, minutes, or hours (for example, throwaway cups, utensils, plastic bags). ${ }^{21}$

These products pollute for decades, centuries, or even thousands of years after their release into the world. For several plastic-exposed ecosystems, this misdevelopment has fatal consequences. In 2007, the US created 254 million tons of garbage and 85 million tons of additional recycled and composted household waste. About $2 \mathrm{~kg}$ of solid waste are produced per person per day in the United States, and plastics represent $10 \%$ of this mass. Recycling present-day synthetic plastics is challenging. We need to rethink at the systems level and encourage measures at the policy and governance level. ${ }^{22}$

While plastics play a central role in modern society, the creation of safer and cleaner products for potential use needs evolving environmental effects and recorded environmental impact. Modern plastics and their components create adverse health and ecological effects, and it should be neutralized where possible. From food and medical equipment to manufacturing items such as polycarbonate, we are using plastics. Intervention is indeed required since many plastics are not biodegradably toxicologically safe. To avoid the continuous accumulation of plastic waste in land and marine habitats, replacement polymers and plasticizers of next-generation should be composed of non-petroleum-based, carbon-neutral monomers, nontoxic, and degradable at a rate sufficient. The classification of products for their durability estimates may be the first step. ${ }^{23}$

Changes in the patterns of plastics manufacture and use are both public health and ethical concern. Following the principle in international environmental law "to not harm in the first place," there are opportunities to shift the global plastics industry towards sustainable growth. This common-sense move could pay significant dividends in resource management and conservation while protecting public health and quality in the environment. ${ }^{24}$

\footnotetext{
21 (Halde, January 13, 2010) p. 188.

22 (Halde, January 13, 2010) p. 188.

${ }^{23}$ (Halde, January 13, 2010) p. 188.

24 (Halde, January 13, 2010) p. 188.
} 


\section{GLOBAL PLASTICS MARKET}

This article analyses the global plastics markets with three categories as below;

- Recycled Plastics

- Filler Masterbatch Compounds

- Original Petrochemicals

\section{C.1. Recycled Plastics:}

Broadly, there are two main ways to recycle plastic:

- Mechanical recycling; where the plastic is washed, ground into powders, and finally melted.

- Chemical recycling; the plastic is divided into monomers and recycled.

The most common technique is the mechanical recycling of LDPE, HDPE, PP, and PET materials.

LDPE:

Recycled LDPE can be used in household goods such as plastic wraps, food sacks, frozen food containers, squeezable bottles, and secure plastics. Recycled LDPE is commonly obtained from LDPE film scraps, rolls, and bubble wraps.

\section{HDPE (High-Density Polyethylene):}

HDPE is another recyclable plastic that is considered clean. The risk of leaching into food or liquids is very low in HDPE items. HDPE can be found in milk cans, yogurt boxes, and containers for cleaning products, body lotion bottles, etc. Many toys for kids are made of HDPE as well. The recycled HDPE can be used in plums, plastic wood, picnic tables, and bottles.

\section{PP (Polypropylene):}

Another safe plastic, PP, can be found in syrup bottles, medicine bottles, pipes, fittings, cans, crates, and containers. PP is recycled into heavy-duty items like pallets, ice scrapers, rakes, and battery cables. Many recycling programs accept PP.

PET:

PET plastics are commonly regarded as clean but can absorb smells from foods and liquids stored on them; they are typically found in beverage bottles and permeable food containers. Most recycling programs support the recycling of PET. Recycled PET can be used for winter clothes, tapestries, furniture, and fibers.

\section{C.1.1. General Information on Recycling Industry:}


The use of polymers in the world has risen sharply in recent years because of population growth. Consumption is related to the increase in demand in the economy we live in.

Current statistics for Western Europe estimate the annual total consumption of plastic products at 48.8 million tons for 2003 , corresponding to $98 \mathrm{~kg}$ per capita. The same quantity a decade before, i.e., in 1993 , was approximately $64 \mathrm{~kg} / \mathrm{capita}$. Over $78 \%$ of this total corresponds to thermoplastics (mainly polyolefins, low-density polyethylene, high-density polyethylene, polypropylene) and the remaining to thermosets (mainly epoxy resins and polyurethanes) ${ }^{25}$.

With $42 \%$ of plastics entering the usage process, packaging was the main use of primary plastics. The second highest sector used 19 percent of the overall was building and construction. Primary plastic production does not reflect the generation of plastic waste directly because the material form and durability of the finished product often affect the usage ${ }^{26}$.

Plastic recycling involves the recuperation and reprocessing of waste material into usable items from scrap or used plastics. Recycling is a part of the global movement to eliminate solid waste plastics, as most plastics are non-biodegradable.

By melting together, different types of plastics appear to be separated, such as oil and water, and fall in certain layers. This causes structural weakness in materials, which means that polymer blends are only suitable for narrow applications. The two most commonly produced plastics, polypropylene, and polyethylene reduce their recycling utility with this blending. Additional virgin materials should be added when plastic is recycled in order to maximize material quality. It is only possible to recycle the same plastic product about 2-3 times before its consistency is reduced to the extent where it can not be used more.

\section{C.1.2. Mechanical Recycling:}

Mechanical plastics recycling means processing plastic waste into recycled products without altering the chemical composition of the material. All thermoplastics can, in theory, be recycled mechanically with a low to no decline inefficiency. It is now nearly the only method of recycling in Europe, with a rate of over $99 \%$.

Mechanical recycling for post-consumer waste is currently the primary recycling technique used in the industry ${ }^{27}$. The aim of mechanical recycling is to recover plastics through mechanical processes (grinding, washing, separation, drying, granulation and composition) and to produce recycled polymers that can be converted into plastics and replace virgin plastics. It is also defined as material recycling or back-to-plastics recycling.

In the mechanical recycling method, sorted plastic waste is being milled and washed in. After that flotation separation, they are being dried. The plastic flakes are then either used directly to make new

\footnotetext{
${ }^{25}$ (Achilias, Roupakias, P. Megalokonomosa, A.A. Lappas, \& E.V. Antonakou, 2007) p. 536.

${ }^{26}$ (Ritchie, 2018)

${ }^{27}$ (e.V., JUL 2020) p. 2.
} 
products or refined in advance into granules. Both in the recycling of pre-consumer and post-consumer wastes, mechanical recycling can be used. It is the dominant recycling process for plastic waste used in the world right now.

In mechanical recycling, thermoplastics can be remelted and processed for later use in injection moldings or extrusion techniques. It is a well-known material recovery technology for materials like polypropylene (PP), polyethylene (PE), or polyethylene terephthalates (PET).

There are two important steps in mechanical recycling;

- Sorting

- Reprocessing

In the sorting step, the plastic waste passes extensive manual and/or automated mechanical sorting processes to separate the different materials. The proper identification of the materials is essential for achieving a maximized purity of recyclates. Various techniques are available to make the sorting process more effective, such as "near-infrared (NIR)," "laser," or "x-ray." While the sorting technology has improved its precision, the sorting efficiency is never $100 \%$ due to the separation defects and items laminated or blended, which can not be separated.

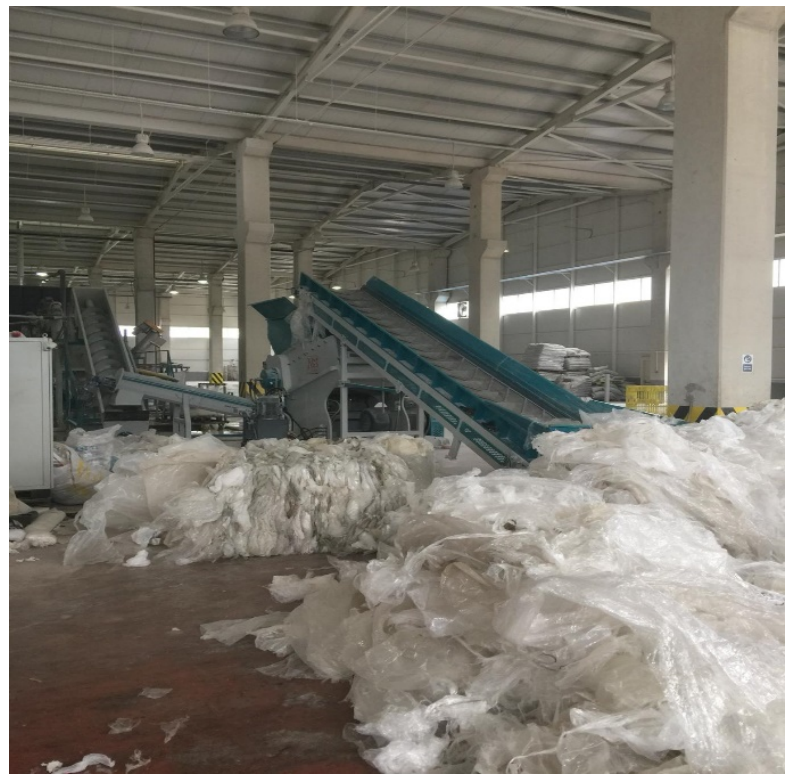

Sorting Process in LDPE Recycling Facility - ELM Kimya AS.

The materials are recuperated by recycling and granulation after the cleaning and grinding process. With all common systems for plastic conversion, it is possible to process the subsequent recyclates. The heat and mechanical decomposition of polymers can cause higher temperatures and tensile strengths during melting and reprocessing, which can affect the length and distribution of the polymer chain. This can impact material properties as for example, crystalline phase or mechanical strength.

If the consistency of the recycled material is convenient enough after sorting and processing, the same or similar items may be produced with these materials. Virgin plastic materials can be replaced by 
recycled plastic materials that would lead to a circular economy. However, today, recycling technology only permits us to apply recycled materials to lower value products ${ }^{28}$.

\section{C.1.3. Applications In The Industry:}

In a wide range of applications, recycled polymers can be used. Some plastics, especially those consisting of mixed materials, low-value end products, products where wood or concrete are substituted, particularly outdoor applications, are some of the applications that recycled materials may be used. In applications similar to those from which they are recovered, recycled raw materials may be used easily. This is called closed-loop recycling. The recycling application is significantly downgrading the quality of the products, so the reflection of the relatively low resin properties should always be considered while using the recycled material.

PET bottles are recycled for the production of new PET bottles, also for films, panels, and nylon straps. PET can also be recycled to fabrics and materials in polyester. The majority of the PET bottles are clear, and technologies are well-stable for the recycling of these materials. Reuse of PET in new beverage bottles is ideal with recycled materials ${ }^{29}$.

PE and PP bottles and rigid containers are also widely recycled. End-uses include new bottles, trash bags, irrigation and drainage pipes, and auto parts. PE and PP packaging tend to come in different colors, and more often with direct printing or labels integrated into the package. "Natural" colored recycled PE and PP are less common. Incoming "natural" materials, for example, PE milk and water jugs, must be segregated early in the recycling process. Some recycling processes include color sorting or color matching the incoming materials, so the resulting recycled plastics match the desired color. In other applications, all colored materials are mixed, usually resulting in a black or grey recycled material ${ }^{30}$.

Knowing that food industries consume about $50 \%$ of packaging products in the world, among them paper, cardboard, glass, iron, aluminum, and various plastic materials, the recycling issue is tricky in the industry. Without going back to short expiry dates with minimal packaging of fresh products, there are examples of industrial achievements of source reduction of packaging, such as reducing overpackaging. The use of large packaging volumes is not good for the industry. Distribution of bulk products, deposits, and production of drinks in place of consumption are useful methods. Some initiatives exist, such as manufacturing of marine origin (algae) or biodegradable starch polymers to make packaging films, but the gas barrier properties are causing no possibility to package under a protective atmosphere without resorting to the chemical properties of polymers ${ }^{31}$.

${ }^{28}$ (e.V., JUL 2020) p. 2.

${ }^{29}$ (View, 26 November 2018)

${ }^{30}$ (View, 26 November 2018)

${ }^{31}$ (Girardon, 2019) p. 681. 


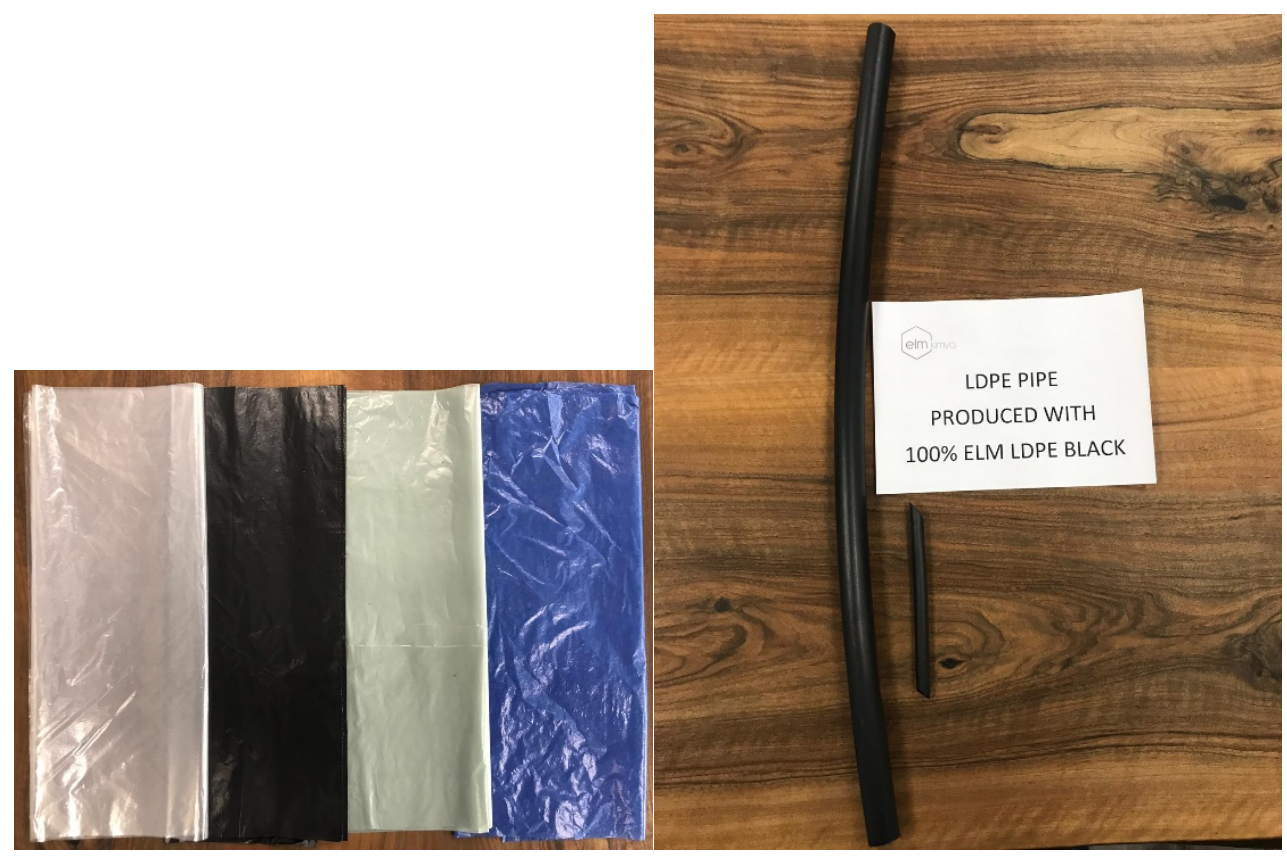

LDPE Films and LDPE Pipes Produced with Recycled LDPE Materials of ELM Kimya

\section{C.2. Filler Masterbatch Compounds:}

In filler masterbatch compounds, additive materials are being used to enhance specific properties and make the product cheaper. Elastomers and plastics are the two largest segments of the filler masterbatch industry. Every year, in the paper, plastics, rubber, paints, coats, adhesives, and sealants industries, over 53 million tons (total value around the US $\$ 18$ billion) of fillers are being used ${ }^{32}$.

Calcium carbonate, precipitated calcium carbonate (PCC), kaolin, talc, and carbon black are the most used materials for filler applications.

Filler masterbatch is today commonly used for many economic benefits in the plastics industry. Plastics based masterbatch compounds are powdered with calcium carbonate and other additives. These materials are usually used for plastic filling to replace the very costly percentage of virgin polymer.

Filler masterbatch provides plastic producers with cost savings. Filler Masterbatch is advantageous not only to plastics producers but also to boost manufacturing conditions by reducing production costs and replacing a portion of the virgin polymer by increasing output. It increases calcium carbonate loading, makes easier pelletization, a cleaner environment, and many other physical and chemical characteristics of plastic products.

32 (Ceresana, 2020) 


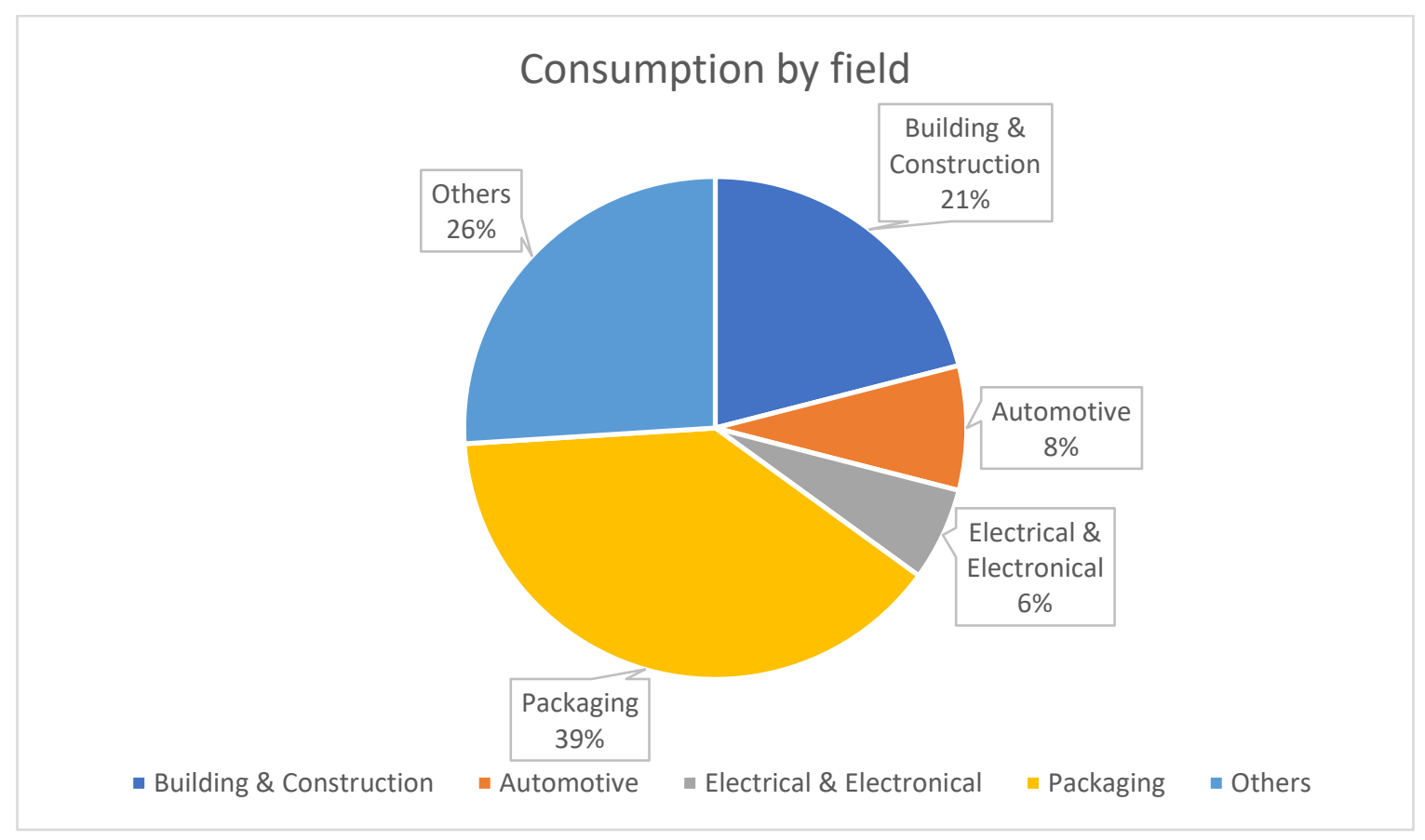

Masterbatch consumption by fields ${ }^{33}$

\section{C.2.1. Methods for Masterbatch production:}

A polyolefin is a polymer type manufactured as a monomer from a simple olefin (also known as an alkene in the chemical equation $\mathrm{CnH}_{2} \mathrm{n}$ ). Polyethylene, for example, is the polyolefine formed by olefin ethylene polymerization. Polypropylene is another common polyolefin derived from propylene olefin. Most polyolefins are produced on an industrial level, which is made by polymerization via catalysts method. The use of the Ziegler-Natta catalyst for ethylene to polymerization is one example.

Thermoplastic olefins typically consist of a thermoplastic, an elastomer, or rubber and filler. If we make a designation between these materials, we can make three groups as below;

- Thermoplastic polyolefins: polyethylene (PE), polypropylene (PP), polymethyl pentene (PMP), polybutene-1 (PB-1).

- Polyolefin elastomers (POE): polyisobutylene (PIB), ethylene-propylene rubber (EPR), ethylene propylene diene monomer (M-class), rubber (EPDM rubber) ${ }^{34}$.

- Fillers such as talc, fiberglass, carbon fiber, and metal oxy sulfate.

In many applications, polyolefin compositions are commonly used, including molded products and films. Different techniques may be applied to enhance the properties of polyolefin compounds used in extrusion and injection moldings. Filled polyolefin materials are stated to be useful in several areas,

\footnotetext{
${ }^{33}$ (Plastics Europe, 2010)

${ }^{34}$ (Cossee, February 1964)
} 
including automotive parts, and are commonly used in extrusion and injection molding processes. The introduction of fillers in polyolefin formulations offers both an economic advantage and better formulations for production ${ }^{35}$.

In a variety of markets, commercially available filler masterbatches have been used. Masterbatches are easy to formulate and usually are used to simplify manufacturing, but not to give the end product unique properties ${ }^{36}$.

Additives such as "antioxidants," "light stabilizers," "heat stabilizers," "nucleating agents," "colorers," and "fillers" may be used in the masterbatch compositions. Polyolefin masterbatches developed from these compositions are shown to be useful for the production of injection molded products, for example, automobile bumpers. These materials provide an acceptable balance of physical properties, including bending modulus, resistance to impact and gloss, and reduced surface defects ${ }^{37}$.

Mixing a rubber polymer material and filler can be a method for creating free-flowing filler masterbatch powder. This process consists of intimately combining a polymer material and a filler in a range of 25 to 70 percent for one to five minutes. The components may be transformed into a freeflowing structure in the mixer. It is shown that the free flow composition is useful for the development of molded or extruded items like tires, sheets, rooftop sheets, windshields, cables, cabling boards, and wires ${ }^{38}$.

\section{C.2.2. Application in the Industry:}

The application areas of filler masterbatch compounds are mainly;

- Packaging

- Building and construction

- Consumer goods

- Automotive

- Textiles

The polymer-based masterbatch is used for easy and cost-effective processing of products with plastics like Polypropylene (PP) Filler Masterbatch and Polyethylene (PE) Filler Masterbatch.

$\mathrm{CaCO} 3$ filler masterbatch can be used in the packaging industry to make PE heavy bags, PE liquid packaging films, sanitary products bags, agricultural films, $\mathrm{PE}$ handbags, $\mathrm{PE}$ garbage bags. Use of $\mathrm{CaCO}^{3}$

\footnotetext{
35 (MI, (US) Patent No. US 2005/0250890 A1, May 5, 2005 )

${ }^{36}$ (MI, (US) Patent No. US 2005/0250890 A1, May 5, 2005 )

37 (MI, (US) Patent No. US 2005/0250890 A1, May 5, 2005 )

38 (MI, (US) Patent No. US 2005/0250890 A1, May 5, 2005 )
} 
filler masterbatch in blow molding can increase container's ESCR ${ }^{39}$ property, get better dimension stability, and in injection molding, it can improve low-temperature impact resistance strength, get better dimension stability ${ }^{40}$.

There is an increase in demand for different types of filler masterbatch compounds for replacing metals to cut vehicle weight and improve fuel efficiency in the automotive industry. Modified polypropylene material with low density, resistant to chemicals, has the advantage of easy processing and cost-effectiveness, thereby be widely used, especially on automobile parts. Such an application in the automotive industry makes the plastics industry pay close attention to the filler masterbatch market. ${ }^{41}$

\section{C.3. Polymers:}

The global demand for polymers is growing quickly. Plastics production has risen twenty times since the $1960 \mathrm{~s}^{42}$. It is estimated that the global polymers market will reach about 546 billion dollars in 2020 and will be steadily rising in 2025 to 693 billion dollars by 2025. The growth of the global polymers market is driven by an increase in demand for polymers from diverse end-use industries, such as health care, building, packaging, automobiles, etc ${ }^{43}$.

Building industry development has helped raise the demand for plastics for 2018 and 2019 in emerging markets such as Brazil, China, India, or Mexico. However, the recent COVID-19 outbreak has hindered plastics demand for various applications, including building, automotive, electrical products, and consumer goods. Production is being halted, supply and transport restrictions and global economic downturn are also being constrained ${ }^{44}$.

Polyethylene, with a share of 25.7 percent in 2019 , dominates the industry for revenue. The large consumption of containers, bottles, plastic sacks, plastic films has led to a growing demand for plastics in the packaging industry.

\footnotetext{
environmental stress crack resistance test - 29 June 2009)

${ }^{40}$ (NHAT HUY GROUP, 2018)

${ }^{41}$ (Guangzhou, China Patent No. CN 102070833 A , 2011.05.25)

42 (Industry Europe, 2018)

${ }^{43}$ (Research and Markets, 2020)

${ }^{44}$ (Grand View Research, Inc., Jun, 2020)
}

${ }^{39}$ Environmental stress cracking resistance; is one of the most common causes of unexpected brittle failure of thermoplastic (especially amorphous) polymers. According to ASTM D883, stress cracking is defined as "an external or internal crack in a plastic caused by tensile stresses less than its short-term mechanical strength". This type of cracking typically involves brittle cracking, with little or no ductile drawing of the material from its adjacent failure surfaces. This behavior is especially prevalent in glassy, amorphous thermoplastics. Amorphous polymers exhibit ESC because of their loose structure which makes it easier for the fluid to permeate into the polymer. (Byoung-Ho Choi Jeffrey Weinhold David Reuschle Mridula Kapur - Modeling of the fracture mechanism of HDPE subjected to 
Emerging innovations have helped polymer manufacturers produce innovative products that give advantages against conventional materials like glass, metals, paper, wood, and leather. Plastic materials are being chosen in many new industries for low costs, availability of raw materials, efficiency in use, and fast production.

The global market of polymers is divided into types, products, applications, and regions. The product applications can also be divided into packaging, electronics, food, petrochemicals, medical, construction \& building, and transportation. The packaging industry continues to dominate the market with the assumption that it will remain the leading industry during the forecast period of 2025.

The market players face severe challenges in rising ecological concerns, efficient disposal, and recycling of plastics, sustainability, and raw material costs. Producers must deliver materials easily used more sustainably by product designers and take advantage of innovative new raw material sources to enhance the quality of recycled and bioplastic products. They could also use the limitless possibilities of innovative solutions to secure modern applications with high quality and create solutions for environmental concerns ${ }^{45}$.

\section{C.3.1. European Market:}

The European plastics sector contributes considerably to European welfare through development, raising people's living standards, and resource efficiency. More than 1,6 million people work in over 60,000 enterprises, creating more than 360 billion EUR annually ${ }^{46}$. However, creative and sustainable growth is also needed for environmental protection.

In 2018, global plastics production almost reached 360 million tonnes; 62 million tonnes of production was from Europe. When the distribution of European plastics applications by industry is analyzed, packaging and construction by far represent the largest end-use markets. The third biggest end-use market is the automotive industry;

- $\quad 39.9$ \% Packaging

- $\quad 19.8$ \% Building \& Construction

- $\quad 9.9 \%$ Automotive

- $\quad 6.2 \%$ Electrical \& Electronic

- $\quad 4.1 \%$ Household, Leisure \& Sports

- $3.4 \%$ Agriculture

- $\quad 16.7$ \% Others (Includes Appliances, Mechanical Engineering, Furniture, Medical, Etc.) ${ }^{47}$

\footnotetext{
45 (Industry Europe, 2018)

${ }^{46}$ (PlasticsEurope, 2019)

${ }^{47}$ (PlasticsEurope, 2019)
} 
On the recycling side, since 2006, the amount of plastic waste sent to recycling has doubled in Europe, and the quantity of plastic post-consumer packaging waste sent to recycling has increased by 92\%. The Directive (EU) 2018/852 on Packaging and Packaging Waste sets higher recycling targets per material ( $50 \%$ for plastic packaging by 2025 and $55 \%$ by 2030), together with a new calculation method of recycling performances ${ }^{48}$.

\section{C.3.2. North American Market:}

With a market share of over $51 \%$, Asia-Pacific is the region with the greatest plastics demand; North America, Western Europe, Eastern Europe, and South America follows. China and the USA are the major consumers of plastics worldwide ${ }^{49}$. In North America, the USA has represents the largest market share in plastic usage with electrical \& electronics, health \& pharmaceuticals, packaging, and automotive industries.

In 2018, the USA was the biggest trade partner of the European Plastics Industry ${ }^{50}$. As a critical supply chain intermediary, the plastics wholesaling industry is integral to the US Manufacturing sector. Plastics wholesalers distribute resin and plastic materials to plastic product manufacturers. Industry clients use raw plastic and resin inputs to manufacture an assortment of plastics products, including soft drink bottles, furniture, electronics, pipes, and fittings ${ }^{51}$.

The supply of polymers is likely to be disrupted, considering that demand from industries such as automotive and construction has decreased in North America and elsewhere in the world following the COVID-19 pandemic. Crude oil prices declined significantly due to lack of storage and over-supply. Global production rates were also decreased by the reduction in manufacturing activities in different industries and increased lockdown restrictions. Nevertheless, the market will continue to function due to the demand for plastics from the health care sector for medical equipment such as masks, facial shields, robes, and gloves ${ }^{52}$

\section{C.3.3. Asian Market:}

With a 20.3 percent share of sales in 2019, Asia Pacific has dominated the global plastic market. High economic patterns and consequent household income increase with Southeast Asia's developing economies are raising the revenues in the plastics market. The growth of the production sector further

\footnotetext{
48 (Official Journal of the European Union , 2018)

${ }^{49}$ (Ceresana, May 2017)

${ }^{50}$ (PlasticsEurope, 2019)

51 (IBIS World, June 25, 2020)

52 (Fortune Business Insights Pvt. Ltd., September, 2020)
} 
increases the demand for plastic in the region ${ }^{53}$. In 2018, China reached $30 \%$ of the world's plastics production with more than 100 million tonnes ${ }^{54}$.

However, the COVID-19 outbreak is expected to hamper product demand in construction, automobile, electricity and electronics, and consumer goods industries in countries such as China, India, Japan, Australia, Indonesia, Thailand, and beyond. This outbreak led to a decline or even a stop in manufacturing operations, supply and transport restrictions, and a slowdown in infrastructural activities, which in the coming years could negatively impact the plastics demand for the applications mentioned above.

China is the largest manufacturer and consumer of the Asia-Pacific region for engineering plastics. In recent years, the sufficient supply of raw materials and low production costs have supported production growth in the country's engineering plastics industry. In recent years, the use of engineering plastics has significantly increased due to the rising population, the increasing urbanization, and metal replacement in various industries, such as packaging and automotive. Automotive is one of the fastest-growing industries in the country since, among many other factors, the increase in disposable income among consumers and expanding the manufacturer's automotive production facilities in the country. However, automotive production and sales have declined in the recent past. It is expected that electric vehicles will take over the market in the future ${ }^{55}$.

The use of engineering plastic products in the packaging industry develops rapidly due to its advantages over traditional packaging plastics. As a result of growing exports and domestic consumption in China, demand for food \& drink, consumer goods, and others for packaging materials increases. Recent US-China trade tariffs can decrease the Chinese consumer's reliance on the United States for plastics supplies. It is expected that this scenario will lead China's consumers in the European and Asian Pacific regions to search for other producers of polycarbonate and nylon. Such factors in the country's economic growth are expected to increase the demand for plastics for engineering slightly ${ }^{56}$.

In Russia, a strong growth rate was seen in the polymer production market in the last decade. The production of five basic polymers (polyethylene, polypropylene, polystyrene, PVC, and PETF) has increased by more than $55 \%$ compared to 2010 . The production volume increased by five million tons in 2017, although the demand remained higher than the production.

The country has been importing goods and technology for decades. The production is still insufficient to substitute internal production, and the importing of raw materials and semi-finished products continues. There is a specific demand for engineering plastics in the defense and civil goods industries. Most big firms realize that crude oil needs to be converted into high added value refined oil products. There is more demand for these products, and also there is a higher profit margin ${ }^{57}$.

\footnotetext{
53 (Grand View Research, Inc., Jun, 2020)

54 (PlasticsEurope, 2019)

${ }^{55}$ (Mordor Intelligence, 2019)

${ }^{56}$ (Mordor Intelligence, 2019)

57 (Engineering Chemical Technological Center (ECTC), 2018)
} 


\section{TURKISH PLASTIC INDUSTRY}

\section{D.1. Plastics Market in Turkey:}

Turkey ranks 6th in terms of plastics processing capacity in Europe. The number of plastic products hit $9,959.2$ tons and $\$ 37.8$ billion of value by the end of 2017 . The country comprises 6,877 companies in the fields of plastic products, materials, and machinery ${ }^{58}$.

In Turkey, the plastic industry imports $\% 85$ of its raw material needs from outside. Saudi Arabia, South Korea, Germany, Belgium, and Iran are among the leading countries in raw material imports ${ }^{59}$.

Turkey imports plastic raw materials prices on about \%10 above of the export price. This means; Turkey is importing more value-added materials and exporting low value-added raw materials. The supply of raw materials, compounds, and masterbatches play an essential role in producing new hightech products, high value-added, suitable for use in strategic sectors, and that will meet the changing consumer demands worldwide ${ }^{60}$.

\section{D.2. Masterbatches - Comparison Between Turkey and Global Market:}

Worldwide demand is presumably expected to hit about 75 million tons in 2024 for ground calcium carbonate (GCC), precipitated calcium carbonate (PCC), kaolin, talc, carbon black, and other fillers. According to the market researchers of Ceresana, revenues will increase by an average of $3.2 \%$ per year. ${ }^{61}$

The important producers in the market are;

- Clariant (Switzerland)

- Schulman (United States)

- Polyplast Müller (Germany)

- Vanetti Masterbatches (Italy)

- $\quad$ BASF (Germany)

\footnotetext{
58 (TURKISH PLASTICS INDUSTRY, 2020)

59 (PAGEV, 2020)

${ }^{60}$ (PAGEV, 2020)

${ }^{61}$ (Ceresana, 2020)
} 
According to PAGEV ${ }^{62}$ data, there are about 30 manufacturers and compounders in Turkey, excluding foreign representative offices. Apart from that, 25 foreign companies are also representing Turkey. Approximately $\% 90$ of the total amount of compound consumed domestically are being produced in Turkey. Compound consumption increases in direct proportion to the growth in the plastics industry.

There are five foreign masterbatch manufacturer companies in Turkey established with foreign investment from Saudi Arabia, Israel, Greece, the USA, and Switzerland. Like the compound, domestic consumption of masterbatch increases in parallel with the plastics industry's growth. The approximate value of consumption was 70.000 tons in $2017^{63}$.

With a \%34 of the market, ground calcium carbonate (GCC) is the world's most widely used filler. According to the 2016 data, the region Asia-Pacific region used about $50 \%$ of the global supply. According to researchers, GCC will grow by 2.5 percent annually by 2024 . With a demand of 11.7 million tons, carbon black is the second-largest market area. The rubber industry for carbon black is the most important field of application. It is used as a filler for reinforcement because it significantly improves the friction strength of the tire rubber ${ }^{64}$.

\section{D.3. Recycling in Turkey - Comparison To Global Market:}

According to 2019 data, Turkey currently has 715 waste-sorting and 1,135 recycling facilities, most of them dealing with plastics ${ }^{65}$. Between 3-3.5 million tons of plastic were produced in 2018, and over half of them were plastic bottles. Only around $55 \%$ of total plastic products in the market are recycled.

In 2017, approximately 7 billion USD was spent in Turkey on environmental protection; $49 \%$ of these expenses were waste management and $35 \%$ of wastewater management ${ }^{66}$.

Recycled polymers are covering the raw material needs of manufacturers in Turkey. However, in order to operate recycling lines, recyclers need well-organized waste management systems. Since there are no effective waste management plants in Turkey, waste sources are coming from Europe or the USA. After China's measures to import waste plastics, the EU, the USA, and the UK enhanced their export of the waste materials to Turkey. Therefore, the amount of waste import in Turkey has increased rapidly.

The amount of imported plastic waste, which was 159,569 tons in 2016 , has increased to 261,863 in 2017 and 439,909 tons in 2018. The value of the waste import in Turkey in 2017 was 52 million euros ${ }^{67}$.

\footnotetext{
${ }^{62}$ Foundation of Turkish Plastics Industrialists Research, Development and Education

${ }^{63}$ (PAGEV, 2020)

${ }^{64}$ (Ceresana, 2020)

65 (Zontur \& Hamit, 2019)

${ }^{66}$ (TMMOB ÇEVRE MÜHENDISLERI ODASI, June 2019)

${ }^{67}$ (TMMOB ÇEVRE MÜHENDISLERI ODASI, June 2019)
} 
Plastic waste import from European Union countries to Turkey between 2004 to 2020 has increased 173 times $^{68}$.

In Turkey, 165 thousand tons of PET bottles are produced annually. Only 40 thousand tons of these can be recycled. The monetary value of 125 thousand tons of pet bottles that could not be recycled is 70 million. Furthermore, Turkey is importing $\$ 1.7$ billion per year of synthetic fibers. 1 Billion USD of this expenditure is spent on the import of polyester fiber obtained from recycling ${ }^{69}$.

According to the Plastics Industrialists Association in Turkey (PAGDER), the current overall recycler's capacity approaches 850,000 tonnes; with a steady rise, it will increase to 4.3 million tons by 2030 .

In order to raise awareness about recycling, the zero waste project was launched in 2017, and the public and private sectors widely take it up. The more the project expands, the more recyclable waste and the efficiency and sustainability grows up. Currently, global consumption of plastic is $\mathbf{3 7 0}$ million tons per year, and it is predicted to reach one billion tons in $2050^{70}$; therefore, countries such as Turkey should lean on sustainability projects like this in order to avoid ecological problems related to plastics.

According to environmental observers, when we compare with the world, although the government organizations try to increase the conscience of society with projects like "Zero Waste Turkey," Turkey is not fulfilling the record on recycling and landfill management. Turkey recycles just $1 \%$ of its household waste and sends the rest to landfills. A report conducted in the science journal ranks Turkey as one of the top 20 plastic waste mismanagement countries worldwide ${ }^{71}$.

Compared to the rest of the world, Turkey has still needed lots of investment in the plastics' recycling side.

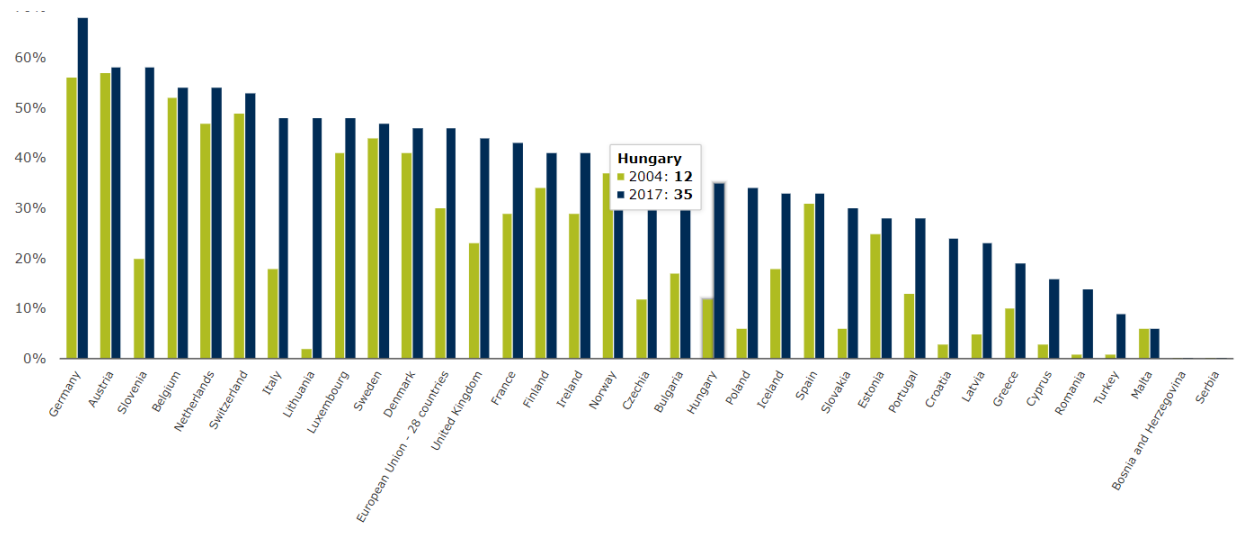

Country comparison - Municipal waste recycled and composted in Europe ${ }^{72}$

\footnotetext{
68 (Vardar, 2020)

${ }^{69}$ (TAYYAR \& ÜSTÜN, 2010)

70 (DAILY SABAH, 2019)

${ }^{71}$ (Saracoglu \& Laville, 2018)

72 (The European Environment Agency, 2019)
} 


\section{E. FINANCIAL AND OPERATIONAL SIDE OF PLASTICS INDUSTRY}

International business transactions and commodity trading methods in the plastics industry require expertise not only on the technical side of the plastics but also legal and operational knowledge about the transactions. Bad plastic waste management has negative environmental and climate impacts, such as plastic and microplastic deposits that occur on land and in marine territories around the world. Therefore there are very strict rules and authorizations in the commerce of these materials ${ }^{73}$.

For example, according to REACH, "Registration, Evaluation and Authorization and Restriction of Chemicals," which is the system for controlling chemicals in the EU and it came into force in 2007 (Regulation 1907/2006). This policy affects nearly every industry, from automotive to textiles. REACH requires chemicals produced or imported into the $E U$ in volumes above 1 ton per year to be registered with a central database handled by the European Chemicals Agency (ECHA). For example, companies from the US cannot register directly and must have their materials registered in customs through their importer or EU-based representative in the system ${ }^{74}$.

\section{E.1. Shipping Methods and Incoterms:}

Shipping chemicals and plastics are complex and specialized. Whether you ship hazardous or nonhazardous materials, every detail of the transportation process matters. The natural gas industry has increased supplies and opportunities for petrochemical manufacturing in the world. As the growth of the petrochemical industry, transportation and warehousing costs have risen.

Due to all of these factors, intermodal transportation is becoming a preferred method of shipping for the petrochemical industry. Many petrochemical companies engage third-party logistics partners to manage the intermodal transportation of goods in order to save time and money.

The packaging is also very important in plastic shipping. A flexible intermediate bulk container made of thick woven polyethylene or polypropylene, either coated or uncoated, is usually used for packing the polymers to make them ready for shipping. They normally measure around $114-122 \mathrm{~cm}$ in diameter and varies in height from 100 to $200 \mathrm{~cm}$. Capacity is normally around $1,000 \mathrm{~kg}$, but the larger units can store even more. The carriage and loading take place in pallets or by removing them from the loops. The bags consist of one, two, or four elevation loops ${ }^{75}$.

Also, 20 or $25 \mathrm{~kg}$ bags are being used to make compliance with Health \& Safety Manual Handling Guidelines easier. These bags are being stretched to pallets in order to keep the bags on the pallet during transport. Originally pallets were $1,000 \mathrm{kgs}$, although in order to achieve better pallet utilization and

\footnotetext{
73 (The European Environment Agency, 2020)

${ }^{74}$ (Commercial Specialists and the CS Manufacturing Team, March 2018)

75 (Truro, Canada Patent No. US006062732A, Jul. 10, 1998)
} 
transport efficiency, pallets now typically are 1,375 kgs ( $55 \times 25 \mathrm{~kg}$ bags). Depending upon vehicle type, this has enabled delivery size to increase from 20 tonnes to 27.5 tonnes on the same 20 pallets.
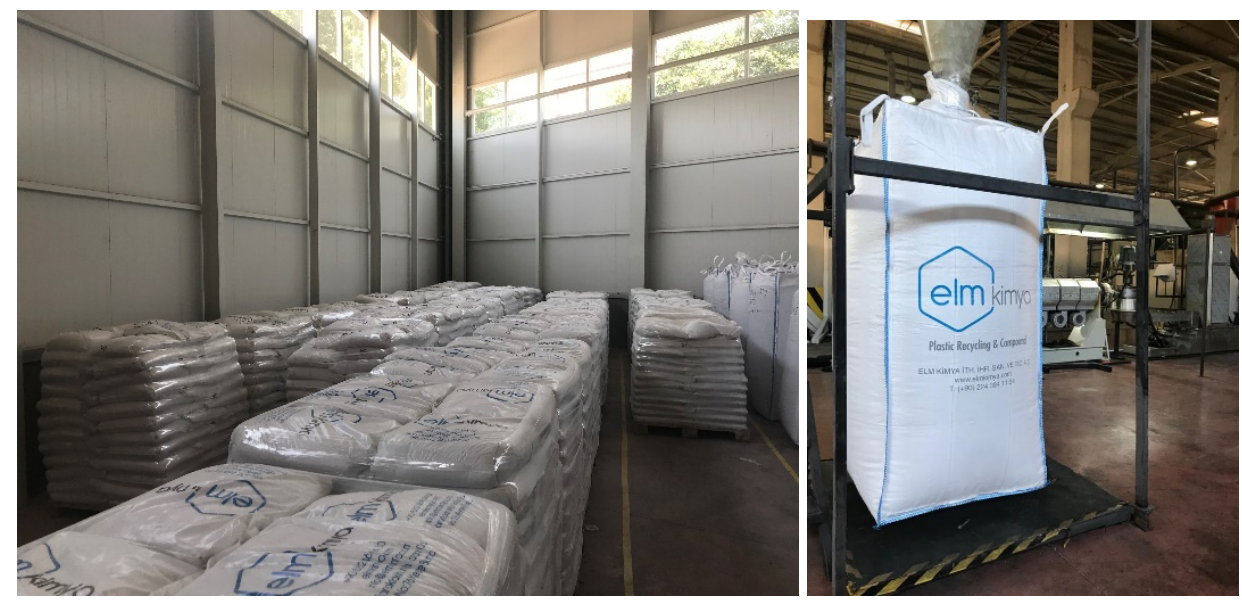

ELM Kimya $25 \mathrm{~kg}$ bags and $1250 \mathrm{KG}$ Big Bag

\section{Incoterms / Terms of Sales:}

The 'Incoterms' or 'International Commercial Terms' published by the 'International Chamber of Commerce (ICC) are pre-defined international commercial law terms. They are commonly used in international business or purchase transactions and are promoted by trade unions, tribunals, and international lawyers ${ }^{76}$. In most petrochemical transaction; the incoterm is decided as EXW, FOB, or CIF according to the agreement between parties.

These are terms that define the obligations, risks, and costs of the buyer and seller. They include the delivery of goods, which are the most important terms for creating the transaction. Incoterms are designed according to the modes of transport, either any mode of transport or sea and inland waterway transport terms ${ }^{77}$.

In 'Incoterms' there are some expressions of particular significance, some of which are essential such as; "Delivery", "Arrival", "Free", "Carrier", "Freight forwarder", "Terminal" and "To clear for export". In "Incoterms", parties should be cautious about their purpose and variations. The parties should clearly express their wish and refrain from casual adoption. In addition, they should also carefully make amendments or modifications with the definition of a certain word because an error can cause unexpected results. ${ }^{78}$

Currently, according to INCOTERMS 2020, there are 11 rules that can be adopted by the parties;

\footnotetext{
76 (ICC Academy, 2020)

77 (AIT Worldwide Logistics, Inc, 2020)

78 (Vishny, 1981)
} 
- Ex Works (EXW)

- Free Carrier (FCA)

- Carriage Paid To (CPT)

- Carriage and Insurance Paid To (CIP)

- Delivery at Place (DAP)

- Delivered at Place Unloaded (DPU)

- Delivery Duty Paid (DDP)

- Free Alongside Ship (FAS)

- Free on Board (FOB)

- $\quad$ Cost and Freight (CFR)

- Cost, Insurance \& Freight (CIF)

\section{E.2. Payment Methods In Global Plastic Trade:}

In international trade of plastics materials, like other commodity trading operations, depending on the transaction and relationship between the parties, there are two methods commonly used by the companies:

- Advance Payment via Bank Transfer (TT in Advance)

- Letter of credits

These methods can be used in different conditions and characteristics depending on the countries and the parties who are subject to the transaction. We will observe them in detail in this article.

\section{E.2.1. TT in Advance:}

A "telegraphic transfer" historically refers to a transfer of money via the telegraph. This means sending money via an old cable, radio, or telephone. A transfer is currently just a transfer of money, which is the same as a wire transfer. These methods can be referred to as telex transfer, a TT, a T/T, a TT bank payment, or just a wire transfer; these expressions all mean the same thing ${ }^{79}$.

The sender or receiver informs their bank that they want to send money to the receiver or beneficiary during a standard international telegraphic transfer. This can be done via a branch, via mail or fax, online, or mobile banking, depending on the bank and its policy. The bank of the sender then transfers the money to a bank, which operates in the country or area of the recipient. The funds will be

79 (TransferWise, 18) 
converted into the required currency and deposited into the account of the receiver, who has a bank account in that currency. Then conversion will be completed. Otherwise, the bank functions as a broker. They may also make the change and charge a small percentage of the transfer fee until it moves the money to another temporary bank or the bank of the recipient.

'Wire transfers' and "telegram transfers" are the same, which can also be called 'money transfers,' 'international transfers,' or 'SWIFT transfers.' Each of them utilizing the SWIFT ${ }^{80}$ system, a secure messaging system used by banks to send each other messaging and instructions for sending money across borders rapidly and accurately.

'Cash in advance' is one of the best reliable payment conditions for sellers. In fact, only after the full payment has been paid can the Seller deliver the items to the buyer ${ }^{81}$. In the petrochemical industry, most of the big producers are accepting cash in advance payment before shipping the materials to the distributors or direct users.

\section{E.2.2. Letter Of Credits:}

In global plastic trading, when payment is concerned, global business projects are discouraged with regard to market facts such as distance, geographical barriers, insecurity, and mistrust among business enterprises. Only after selling the imported goods on the domestic market will the buyer indeed pay the seller the cost. On the other side, the seller needs to reimburse 'even prior to shipping' as soon as possible. ${ }^{82}$ Moreover, in a transnational business transaction, where the goods and the payment are not exchanged simultaneously, 'there is a risk that parties to exchange may not fulfill their obligations'. In such a case, 'the seller may take the payment and not give the good, or the buyer takes the good and not give the payment.' Moreover, petrochemical transactions between different countries include different payment systems, conflicts of law, language barriers, incomprehension, and reliability among business partners, and other obstacles. ${ }^{83}$

A letter of credit (LC) is a written document issued on behalf of an importer by the bank of the importer. The exporter is guaranteed by receiving payment for the transaction by the issuing bank. The importer is the LC's claimant, and the exporter is the beneficiary. The issuing bank undertakes to pay the mentioned amount in compliance with the negotiated period and documents inside the LC. An LC's guiding principle is that the issuing bank pays only on the basis of documentation submitted and is not

\footnotetext{
80 The Society for Worldwide Interbank Financial Telecommunication is a network that allows global financial institutions to send and receive data in a confidential, structured and consistent environment about financial transactions.

${ }^{81}$ (Projectmaterials, 2017)

82 (Biswas, September 2011) p. 1.

${ }^{83}$ (Biswas, September 2011) p. 2.
} 
expected to ensure that the goods are physically delivered. If the documents submitted follow the terms of the LC, the bank will confirm the payment. ${ }^{84}$

The illustration below explains the LC transactions;

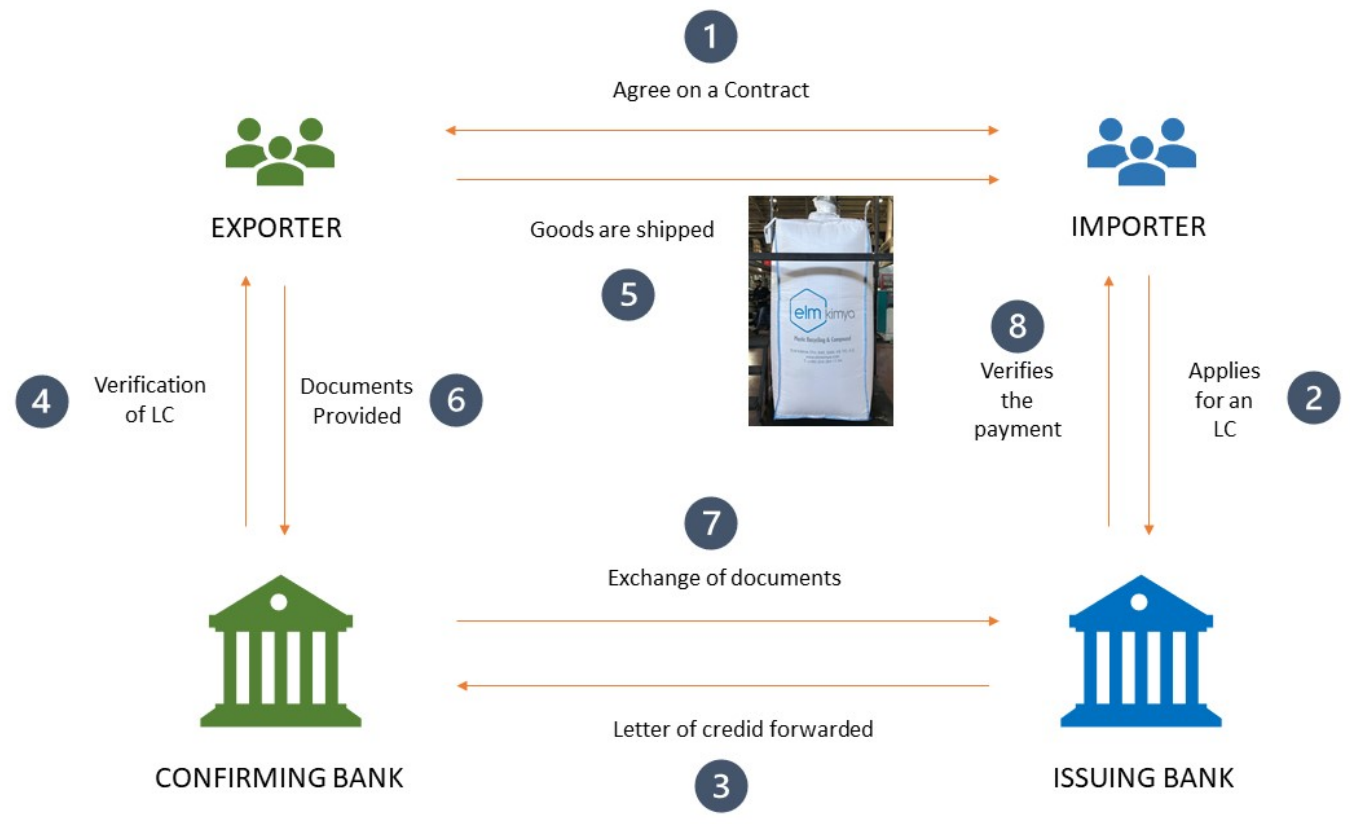

A process flow chart example for how a letter of credit procedure works

1. Issuance of LC;

After the contract and the use of LC have been negotiated by the parties to a trade agreement, an importer makes reference to the issuing bank the issue of LC to the exporter. The LC shall be forwarded to the advisory bank by the issuing bank. Both of these are normally situated in the country of the exporter and may also be the bank of the exporter. The advisory bank verifies the validity of the LC and passes it to the exporter.

2. Shipping of goods;

After receiving the LC, the exporter will check it and start the shipping process of the goods to fulfill the contract.

3. Providing Documents to the confirming bank;

The exporter submits the documents to the bank for advice and confirmation after the delivery of the goods.

${ }^{84}$ (Khajuria, 2020) 
4. Payment settlement and receipt of goods;

On the other side, the bank will give the documents to the issuing bank, and the balance will be paid, approved, or agreed upon as appropriate. The issuing bank examines the documents and collects the importer's payment. The bank will pass the documents to the importer who uses them to receive the goods shipped.

\section{E.2.2.1. Types of $L C$ :}

In global trade, according to the circumstances, there may be used many types of LC as in the list below;

- At Sight LC

- $\quad$ Time/Usance LC

- Differed/Mixed Payment LC

- Revolving LC

- Confirmed LC

- Transferable LC

- Discounting LC

- Standby LC

- Revocable LC

- Irrevocable Letter of Credit

All of these types have different characteristics, and they can be used in different situations.

\section{At Sight LC:}

An LC in sight shall be a letter of credit (LC) payable immediately after the seller meets the conditions of the letter of credit (five to ten days from later). Sellers who frequently export to overseas buyers are the fastest method of payment ${ }^{85}$.

\section{Time/Usance LC:}

"Usance LC," also called "time LC," or "term LC" is also known as "deferred LC." This is a letter of credit payable in advance or in the future, following fulfillment of the conditions in the LC and presentation of confirmatory documents.

To understand a deferred LC, we can compare it to a Sight LC, which is when the corresponding documents are presented, funds are transferred to the supplier at the same time. However, in a Usance Letter of Credit, after receipt of documents by the issuing bank and when these documents comply with the terms of the LC, the issuing bank shall approve the request at a later date and agree to transmit

${ }^{85}$ (PRITCHARD, 2020) 
payment funds in accordance with LC. The buyer thus receives a form of credit terms and receives the purchased product but is able to make payment in the future ${ }^{86}$.

\section{Differed/Mixed Payment LC:}

It is a kind of LC that makes mixing of a part of payment with other types of terms (For example, cash), and the balance can be paid as deferred LC ${ }^{87}$.

\section{Revolving LC:}

It is a sort of credit letter with a long-term commercial partnership between the buyer and seller, and it is preferable if there are regular shipments. Revolving credit letters permit an automatic renewal in particular ways without applying to the bank of the current credit letter to issue a new credit letter ${ }^{88}$.

Revolving LC is one where, after payment, the mentioned sum is restored, which eliminates the need for a new LC. In the case of shipments that are exchanged within a short time with the same conditions, this LC may be used.

\section{Confirmed LC:}

A confirmed LC is a letter of credit in which a second bank payment assures the payment to the seller or exporter if the first bank fails to pay.

The main purpose of having a letter of credit of any sort is the feeling of protection, in particular for the seller. The holder of the letter of credit, i.e., in an international plastic sales transaction, needs to be certain that it receives a payment from the issuing bank if it follows the contract terms, but this is not always applicable. The seller might be unsure whether or not he receives payment for his goods. This uncertainty can be caused by various factors, such as a debatable bank credit risk or political or economic insecurity relevant to the issuing bank's location. For instance, it is questionable that payment of a letter from a bank in Libya because of disturbances in the region. In such cases, it is a reasonable decision to take a second assurance, namely to obtain a verified credit letter.

In order to receive a secondary credit letter, the buyer must follow the same process. The buyer must find a second bank to confirm. In general, the second bank is the seller's corresponding bank.

Instead of a confirmed letter of credit, an unconfirmed letter of credit is one in which only one bank (the issuing bank) has a payment guarantee. The second bank's presence is actually an agent and helps with transaction processing. Transaction protection is the primary aim of using a letter of credit in plastic sales. This security is provided by a standard credit letter. Thus, most credit letters are

\footnotetext{
${ }^{86}$ (PATEL, 2018)

${ }^{87}$ (Aktif Yatırım Bankası A.Ş., 2020)

${ }^{88}$ (Aktif Yatırım Bankası A.Ş., 2020)
} 
unconfirmed credit letters. The confirmed letter of credit is only used whenever there is additional uncertainty ${ }^{89}$.

\section{Transferable LC:}

Transferable LC is used when an intermediary is involved, or a company sells another producer's product. This type of $L C$ is very useful in the plastics trade since there are lots of middleman and distributors of big petrochemical providers working in the industry. The primary beneficiary asks the bank to pass all or part of the payment to the second beneficiary of the payment. The first beneficiary is normally the intermediary or a corporation that sells the goods of another.

A Transferable LC is a documentary credit under which the first beneficiary may apply for a bank that is permitted in a specific form to transfer the credit to one or more subsidiary beneficiaries ${ }^{90}$.

A transferable LC contains a "transferable" clause. The suppliers of the produced goods would need an LC, which is issued on schedule and for the required amount from a bank to guarantee the payment of a buyer to a seller before ordering the product. If a seller wants an LC, the buyer must get an LC from a bank $^{91}$.

The LC may only be transferred under the terms and conditions harmonized with the original LC; however, the terms listed below may be altered;

- The total amount shown in the LC

- The price of the goods

- $\quad$ The shipment time

- The issuance date of documents

- The expiry date

The credit transferred to the second beneficial owner may reduce any or all of the above.

Furthermore, a customer's name may be replaced by the first beneficiary's name unless the initial LC states that a document other than the invoice shall contain the applicant's name.

If all or part of the LC is transferred, the first beneficiary shall reserve the right to replace its drafts and invoices with the drafts and invoices of the second beneficiary. It should also be clearly assigned on whether the bank is entitled to shift the original LC to the second beneficiary.

\footnotetext{
${ }^{89}$ (eFinanceManagement, 2020)

90 (United Overseas Bank Limited Co., 2020)

91 (KAGAN, 2020)
} 


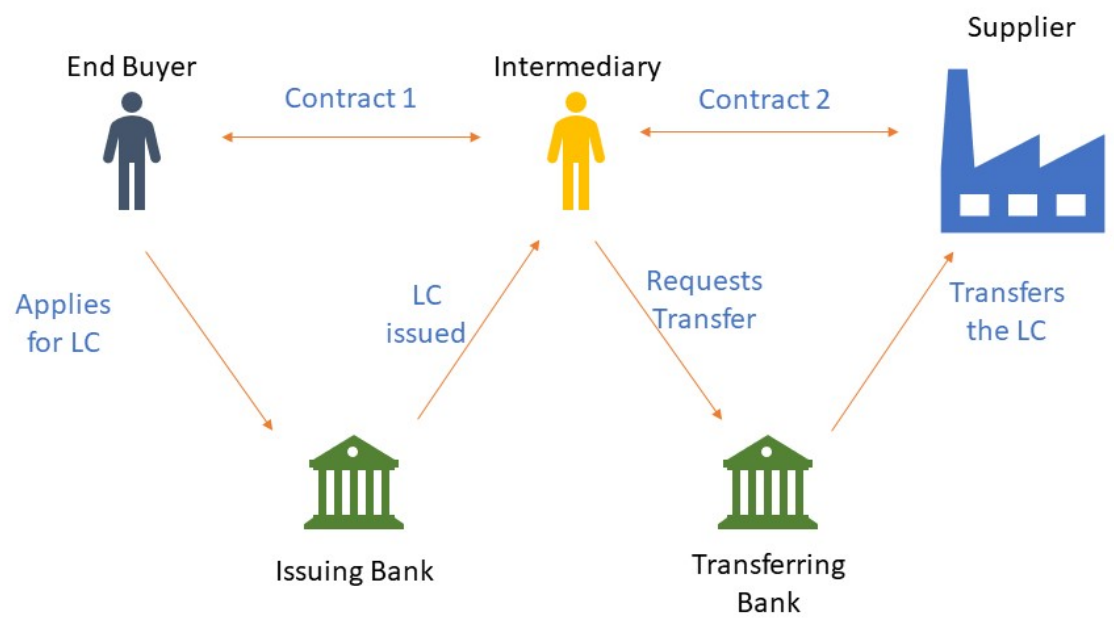

Transferable LC Graphic

\section{Discounting LC:}

Discounting of LC is a short-term form of credit. The bank buys the exporter's documents and bills by way of a letter of credit discount and pays him for a security payment or a charge in return. LC discounting, therefore, facilitates quick discounting of a bill sponsored by LC.

\section{Standby LC:}

A standby letter of credit (SLOC) is a legal document promising a bank's duty to compensate the seller should the buyer - or the client of the bank - refuse to honor the contract. A standby credit letter allows international trade among businesses, which are different laws and regulations and do not know one another. Although the buyer is likely to obtain the products, the SLOC does not guarantee the purchaser's fulfillment with the products ${ }^{92}$.

\section{Revocable LC:}

The issuing bank can, without warning, alter, or revocate Revocable LC independently. In modern international trade, it is seldom practiced.

${ }^{92}$ (KENTON, 2020) 


\section{Irrevocable LC:}

Unless approval from the issuing bank, the beneficiary, and the confirming bank, Irrevocable LC shall not be withdrawn or changed. The exporter can choose to make sure that the sum listed in the LC is charged when the documents submitted meet with the terms and conditions of the contract.

\section{Letter of Credit and Bank Guarantee Distinctions:}

An LC is an undertaking document. It is a guarantee provided to a functioning transaction by the Bank or some other financial institution. It ensures that the importer pays according to the conditions specified in the LC. The letter of credit is issued by four parties: the exporter, the importer, the issuing bank, and the confirming bank.

The Bank guarantee, however, is a commercial device. It is the bank's guarantee that an operation will not malfunction. The bank promises the payment if any fulfillment fails. The bank guarantee process consists of three parties, the claimant, the beneficiary, and the banker ${ }^{93}$.

${ }^{93}$ (Khajuria, 2020) 


\section{REFERENCES}

Achilias, D., Roupakias, C., P. Megalokonomosa, AA Lappas, \& E.V. Antonakou. (2007). Chemical recycling of plastic wastes made from polyethylene (LDPE and HDPE) and polypropylene (PP). Journal of Hazardous Materials, 536-542.

AIT Worldwide Logistics, Inc. (2020, 10 07). How to Use Incoterms ${ }^{\circledR}$ Rules, Common Shipping Terms. AIT Worldwide Logistics, Inc:

https://www.aitworldwide.com/incoterms\#: :text=Incoterms\%20\%2F\%20Terms\%20of\%20Sales, and\%20inland\%20waterway\%20transport\%20terms

Aktif Yatııım Bankası A.Ş. (2020, 10 07). Export Letter of Credit. Aktif Yatırım Bankası A.Ş.: https://www.aktifbank.com.tr/en/corporate/foreign-trade-and-finance/export/export-letter-ofcredit

Baker, B. (2015 , Jan 8). Transferable Letters of Credit. slideshare.net: https://www.slideshare.net/BuddyBaker/transferable-letters-of-credit

Biswas, L. C. (September 2011). Letters of Credit: A Theory on the Legal Basis of the Payment Obligation of Issuing Bank. SSRN Electronic Journal.

Ceresana. (2020, October 31). Global Fillers Market Report. Ceresana:

https://www.ceresana.com/en/market-studies/chemicals/fillers/

Ceresana. (May 2017). Global Plastics Market until 2024. Konstanz: Ceresana.

Commercial Specialists and the CS Manufacturing Team. (March 2018). Plastics Materials and Machinery Export Guide A Reference for US Exporters in the Plastics Industry. Global: US. Commercial Service.

Cossee, P. (February 1964). Ziegler-Natta catalysis I. Mechanism of polymerization of $\alpha$-olefins with Ziegler-Natta catalysts. Journal of Catalysis, Pages 80-88.

DAILY SABAH. (2019, OCT 17). Plastic recycling sets 4.3 million ton goal by 2030. DAILY SABAH: https://www.dailysabah.com/turkey/2019/10/17/plastic-recycling-sets-43-million-ton-goal-by2030

Dassault Systèmes. (2020, 09 28). Introduction to plastic. Dassault Systèmes: https://make.3dexperience.3ds.com/welcome

e.V., E. B. (JUL 2020). MECHANICAL RECYCLING FACT SHEET . Berlin: European Bioplastics e.V.

eFinanceManagement. (2020, 10 07). Confirmed Letter of Credit. http://efinancemanagement.com/: https://efinancemanagement.com/sources-of-finance/confirmed-letter-ofcredit\#: :text=A\%20confirmed\%20letter\%20of\%20credit,method\%20used\%20for\%20internation al\%20trade 
Engineering Chemical Technological Center (ECTC). (2018, 06 08). Polymer production in Russia: problems and prospects. Engineering Chemical Technological Center (ECTC): https://ect-center.com/blogen/new-polymer

Fortune Business Insights Pvt. Ltd. (September, 2020). Plastics Market Size, Share \& COVID-19 Impact Analysis, By Type, By End-Use Industry, and Regional Forecast, 2020-2027. Maharashtra, India: Fortune Business Insights Pvt. Ltd.

Geyer, R., Jambeck, J. R., \& Law, K. L. (19 Jul 2017). Production, use, and fate of all plastics ever made. Science Advances Vol. 3, no. 7, 1-5.

Girardon, P. (2019). Chapter - 13 Conclusion and Outlook. P. G. Rémy Cachon içinde, Gases in Agro-Food Processes (s. 681-684). Paris, France: Elsevier Inc. .

GlobeNewswire, Inc. (2019, July 16). Masterbatch Market To Reach USD 17.35 Billion By 2026 / Reports And Data. GlobeNewswire, Inc: https://www.globenewswire.com/newsrelease/2019/07/16/1883412/0/en/Masterbatch-Market-To-Reach-USD-17-35-Billion-By-2026Reports-And-Data.html

Grand View Research, Inc. (Jun, 2020). Plastic Market Size, Share \& Trends Analysis Report By Product (PE, PP, PU, PVC, PET, Polystyrene, ABS, PBT, PPO, Epoxy Polymers, LCP, PC, Polyamide), By Application, By Region, And Segment Forecasts, 2020 - 2027. San Francisco, CA: Grand View Research, Inc.

Halde, R. U. (January 13, 2010). Plastics and Health Risks. T. B. Center for Environmental Biotechnology içinde, The Annual Review of Public Health (s. 179-94). Baltimore, Maryland: Center for Water and Health, Bloomberg School of Public Health, Johns Hopkins University.

IBIS World. (June 25, 2020). Plastics Wholesaling Industry in the US - Market Research Report. Global: IBIS World.

ICC Academy. (2020, Sep 26). INCOTERMS ${ }^{\circledR} 2020$ CERTIFICATE. ICC Academy: https://www.edumaritime.net/icc-academy/incoterms-2020-certificate-inco-online

Industry Europe. (2018, April 27). How The Global Polymers Industry Is Evolving. Industry Europe: https://industryeurope.com/how-the-global-polymers-industry-is/

KAGAN, J. (2020, May 24). Transferable Letter of Credit. Investopedia: https://www.investopedia.com/terms/t/transferable-letter-of-credit.asp

KENTON, W. (2020, Jun 29). Standby Letter of Credit (SLOC). Investopedia: https://www.investopedia.com/terms/s/standbyletterofcredit.asp

Khajuria, R. (2020, Apr 28). Letter of Credit : Process, Types \& more. Drip Capital Inc.: https://www.dripcapital.com/resources/blog/letter-of-credit-lc

Li Sheng, H. D. (2011.05.25). Guangzhou, China Patent No. CN 102070833 A .

Loca, N. (2020, 04 10). History of Plastic (part 1/2). Nara Loca Abadi - Recycled Plastic Specialist: https://www.naraloca.com/post/history-of-plastic-part-1-2 
Market Research Future. (2017, 05). Global Commodity Plastic Market, By Type. Market Research Future: https://www.marketresearchfuture.com/statistical-reports/commodity-plastic-market-type2900

Mordor Intelligence. (2019). ASIA-PACIFIC ENGINEERING PLASTICS MARKET - GROWTH, TRENDS, AND FORECAST (2020 - 2025). Hyderabad, India: Mordor Intelligence.

NHAT HUY GROUP. (2018, 11 24). VARIOUS APPLICATION OF USING FILLER MASTERBATCH IN ALL OVER THE WORLD. NHAT HUY GROUP: https://nhathuygroup.com.vn/various-application-of-usingfiller-masterbatch-in-all-over-the-world

Official Journal of the European Union . (2018, 6 14). DIRECTIVE (EU) 2018/852 OF THE EUROPEAN PARLIAMENT AND OF THE COUNCIL of 30 May 2018 amending Directive 94/62/EC on packaging and packaging waste. EUR-Lex: https://eur-lex.europa.eu/legalcontent/EN/TXT/PDF/?uri=CELEX:32018L0852\&from=EN

PAGEV. (2020, 10 07). PAGEV Compound ve Masterbatch Sektörlerinin Sorunlarını Mercek Altına Aldı. Türk Plastik Sanayicileri Araştırma Geliştirme ve Eğitim Vakfı: https://www.pagev.org/pagevcompound-ve-masterbatch-sektorlerinin-sorunlarini-mercek-altina-aldi

PATEL, N. (2018, AUGUST 19). Usance Letters of Credit - What are they? / 2020 TFG Usance LC Guide. Trade Finance Global: https://www.tradefinanceglobal.com/posts/usance-letters-of-credit-whatare-

they/\#: :text=A\%20Usance\%20or\%20a\%20Deferred,discussing\%20a\%20Letter\%20of\%20Credit

Plastics Europe. (2010). An analysis of European plastics production, demand and recovery for 2010. Wemmel - Belgium : Plastics Europe.

PlasticsEurope. ( 2019). Plastics - the Facts. Brussels - Belgium: PlasticsEurope.

PRITCHARD, J. (2020, June 19). LC at Sight: Quick Payment With a Letter of Credit. The Balance: https://www.thebalance.com/lc-at-sight-quick-payment-under-a-letter-of-credit-315038

Projectmaterials. (2017, July 31). 6 Types Of Payment Terms For Exporters. Projectmaterials.com: https://blog.projectmaterials.com/project-procurement/contract-payment-terms-options/

Research and Markets. (2020, April 28). Insights into the Worldwide Polymers Industry to 2025 - Identify Drivers and Challenges for the Market. GlobeNewswire: https://www.globenewswire.com/newsrelease/2020/04/28/2023206/0/en/Insights-into-the-Worldwide-Polymers-Industry-to-2025Identify-Drivers-and-Challenges-for-the-Market.html

Ritchie, H. (2018). Plastic Pollution. OurWorldInData.org: https://ourworldindata.org/plastic-pollution

Rogers, T. (2015, 11 05). Everything You Need To Know About Polystyrene (PS). Creative Mechanisms: https://www.creativemechanisms.com/blog/polystyrene-ps-plastic

Saracoglu, G., \& Laville, S. (2018, Oct 18). Turkey's plastic waste imports from the UK are booming - but at what cost? The Guardian: https://www.theguardian.com/environment/2018/oct/18/ukplastic-waste-imports-to-turkey-boom-but-at-what-cost

Scott, R. (Jul. 10, 1998). Truro, Canada Patent No. US006062732A. 
Special Chem. (2020, 09 10). Polyethylene (PE). Special Chem - The Material Selection Platform: https://omnexus.specialchem.com/selection-guide/polyethylene-plastic

SpecialChem . (2020, 09 10). Comprehensive Guide on Polyvinyl Chloride (PVC). SpecialChem - The Material Selection Platform: https://omnexus.specialchem.com/selection-guide/polyvinylchloride-pvc-plastic

SpecialChem. (2020, 09 10). Polyethylene Terephthalate (PET): A Comprehensive Review. SpecialChem The Material Selection Platform: https://omnexus.specialchem.com/selectionguide/polyethylene-terephthalate-pet-plastic

SpecialChem. (2020, 09 10). The Definitive Guide to Polypropylene (PP). SpecialChem - The Material Selection Platform: https://omnexus.specialchem.com/selection-guide/polypropylene-pp-plastic

TAYYAR, A. E., \& ÜSTÜN, S. ( 2010). Usage of Recycled Pet. Pamukkale Üniversitesi Mühendislik Bilimleri Dergisi, 53-62.

The European Environment Agency. (2019, Nov 22). INDICATOR ASSESSMENT Waste recycling. The European Environment Agency: https://www.eea.europa.eu/data-and-maps/indicators/wasterecycling-1/assessment-1

The European Environment Agency. (2020, Jul 23). BRIEFING: The plastic waste trade in the circular economy. The European Environment Agency: https://www.eea.europa.eu/themes/waste/resource-efficiency/the-plastic-waste-trade-in

TMMOB ÇEVRE MÜHENDISLERI ODASI. (June 2019). DÜNYA ÇEVRE GÜNÜ TÜRKIYE RAPORU. Istanbul: TMMOB ÇEVRE MÜHENDISLERI ODASI.

TransferWise. (18, 05 15). TT payment: meaning and definition. TransferWise: https://transferwise.com/au/blog/telegraphic-transfer-meaning

TURKISH PLASTICS INDUSTRY. (2020, 10 07). Countries' shares within Turkey's exports. TURKISH PLASTICS INDUSTRY: https://www.turkishplastics.net/en/turkish-plasticsindustry/\#: :text=In\%20terms\%20of\%20plastics\%20goods,raw\%20material\%20and\%20machiner y\%20areas

United Overseas Bank Limited Co. (2020). TRANSFERRING OF EXPORT LETTER OF CREDIT . Singapore: United Overseas Bank Limited Co.

Vardar, N. (2020, Mayıs 21). Türkiye'de plastik atık ithalatı son 15 yılda 173 kat arttı. Greenpeace: https://www.greenpeace.org/turkey/basin-bultenleri/turkiyede-plastik-atik-ithalati-son-15-yilda173-kat-artti/

View, F. P. (26 November 2018). David I.Clark. Ann Arbor, MI, United States: Amcor Limited.

Vishny, P. H. (1981). Guide to International Commerce Law. St. Paul: McGraw-Hill Companies.

WARING, S. (2017, DECEMBER 7 ). BAKELITE: THE FIRST SYNTHETIC PLASTIC. Science Museum Group: https://blog.sciencemuseum.org.uk/bakelite-the-first-synthetic-plastic/ 
Yan Chen, C., Myles, J., Rengarajan, R., \& Sparhawk, B. (May 5, 2005 ). MI, (US) Patent No. US 2005/0250890 A1.

Zontur, E. C., \& Hamit, D. (2019, 10 27). Turkey should focus on plastic waste for economy, planet: Expert. Anadolu Agency: https://www.aa.com.tr/en/environment/turkey-should-focus-on-plastic-wastefor-economy-planet-

expert/1627522\#: :text=Recycling\%20in\%20Turkey\&text=According\%20to\%20this\%20portal\%2 C\%20around,in\%20the\%20market\%20are\%20recycled 